\title{
Themes in Train-the-Trainer Nutrition Education Interventions Targeting Middle School Students: A Systematic Review
}

\author{
Christine St. Pierre ${ }^{1, *}$, Win Guan ${ }^{2}$, Leah Barry ${ }^{3}$, Grace Dease ${ }^{1}$, Sydney Gottlieb ${ }^{3}$, Arielle Morris ${ }^{4}$, \\ Jamison Merrill ${ }^{2}$ and Jennifer M. Sacheck ${ }^{1}$ (D) \\ 1 Milken Institute School of Public Health, The George Washington University, Washington, DC 20052, USA; \\ gdease@gwu.edu (G.D.); jsacheck25@gwu.edu (J.M.S.) \\ 2 Up2Us Sports, New York, NY 10018, USA; wguan@up2ussports.org (W.G.); jamisonmerrill@gmail.com (J.M.) \\ 3 Department of Sociology, Tulane University, New Orleans, LA 70118, USA; lbarry2@tulane.edu (L.B.); \\ sgottlieb@tulane.edu (S.G.) \\ 4 School of Science \& Engineering, Tulane University, New Orleans, LA 70118, USA; amorris12@tulane.edu \\ * Correspondence: cstpierre@gwu.edu; Tel.: +1-202-994-5737
}

check for

updates

Citation: St. Pierre, C.; Guan, W.; Barry, L.; Dease, G.; Gottlieb, S.;

Morris, A.; Merrill, J.; Sacheck, J.M.

Themes in Train-the-Trainer Nutrition

Education Interventions Targeting

Middle School Students: A

Systematic Review. Nutrients 2021, 13 ,

2749. https://doi.org/

$10.3390 /$ nu13082749

Academic Editor: Melissa Melough

Received: 9 June 2021

Accepted: 5 August 2021

Published: 10 August 2021

Publisher's Note: MDPI stays neutral with regard to jurisdictional claims in published maps and institutional affiliations.

Copyright: (c) 2021 by the authors. Licensee MDPI, Basel, Switzerland. This article is an open access article distributed under the terms and conditions of the Creative Commons Attribution (CC BY) license (https:/ / creativecommons.org/licenses/by/ $4.0 /)$.

\begin{abstract}
Context-appropriate nutrition education interventions targeting middle school students have the potential to promote healthy dietary patters that may help prevent unnecessary weight gain at a point in childhood development when youth experience increasing agency over their food choices. The aim of this review was to identify and synthesize themes in train-the-trainer approaches, intervention content and delivery, and youth receptivity across teacher, mentor, and peer-led nutrition education interventions that targeted middle school-age youth in urban, primarily low-income settings. A systematic, electronic literature search was conducted in seven electronic databases, PubMed/Medline, CINAHL, ERIC, PsycINFO, Scopus, SPORTDiscus, and Cochrane CENTRAL, using fixed inclusion and exclusion criteria. A total of 53 papers representing 39 unique interventions were selected for data extraction and quality assessment. A framework synthesis approach was used to organize the interventions into six categories and identify themes according to whether the intervention was classroom-based or out-of-school-based and whether adults, cross-age peers or same-age peers delivered the intervention. Ten of the interventions contained multiple components such that they were included in two of the categories. The review findings indicated that trainings should be interactive, include opportunities to role-play intervention scenarios and provide follow-up support throughout intervention delivery. Interventions targeting middle school youth should include positive messaging and empower youth to make healthy choices within their specific food environment context.
\end{abstract}

Keywords: nutrition education; middle school; train-the-trainer; peer-leaders; obesity prevention; systematic review

\section{Introduction}

The prevalence of childhood obesity in the United States is a major public health concern, particularly because obesity in youth often persists into adulthood and is associated with multiple chronic diseases, increased health care costs, and diminished quality of life [1,2]. Obesity prevalence is significantly higher among non-Hispanic black and Hispanic youth compared with non-Hispanic white and non-Hispanic Asian youth [3], and obesity prevalence tends to be higher in youth from households with lower head-ofhousehold education levels and incomes [4]. Regular physical activity and healthy eating patterns are both important habits for obesity prevention, yet the vast majority of U.S. youth do not meet physical activity or fruit, vegetable, and water intake recommendations [5-7]. Historically under-resourced, urban neighborhoods in the U.S. have high concentrations of the populations identified as being at greatest risk for childhood obesity, and structural inequities in the built and food environments in these communities can make healthy 
choices even more difficult. Accordingly, obesity prevention interventions that target the physical activity and nutrition habits of at-risk youth have the potential to improve health outcomes in these communities for years to come.

Previous reviews that have examined the effectiveness of nutrition education interventions targeting youth, primarily in school-based settings, suggest the following components are important for successful interventions: behaviorally focused education, use of theoretical methods (e.g., skill building, self-assessment, social support, etc.), adequate dosage, and thorough training for those delivering the intervention [8-12]. Despite evidence for the importance of training and a reliance on those outside the nutrition profession-from classroom teachers to out-of-school program volunteers to older student peers-to deliver intervention programming, there is a lack of information on the most effective training methods for those delivering nutrition education interventions (e.g., training-the-trainer models). Furthermore, most reviews have lumped middle school age students with either elementary or high school students, rather than focusing specifically on strategies for targeting this age group as they are transitioning to adolescence and gaining increased agency over their food choices. The purpose of this review, therefore, was to build a larger evidence base for early adolescent nutrition education programs by identifying and synthesizing themes in training approaches, intervention content and delivery, and youth receptivity across teacher, mentor, and peer-led nutrition education interventions that targeted middle school-age youth in urban, primarily low-income settings.

\section{Methods}

This systematic review was conducted in accordance with the criteria set forth in the Preferred Reporting Items for Systematic Reviews and Meta-Analysis (PRISMA) [13]. While we searched the International prospective register of systematic reviews (PROSPERO) to ensure we were not duplicating a similar review, we did not register our protocol due to time constraints for finalizing our review and COVID-19 related processing delays at the time our protocol was developed. Primary research articles, protocol papers, and process evaluation papers were identified by searching PubMed/Medline, CINAHL, ERIC, PsycINFO, Scopus, SPORTDiscus, and Cochrane CENTRAL. The search strategy was developed by the research team and reviewed by a research librarian prior to initiation. An example of the search term strategy is provided in Supplementary Material Figure S1. The search was conducted in May 2020 and limited to English language results published between 2005 and 2020. The search was limited to results published in 2005 and later because it was in the middle part of the 2000s when the literature began to expand beyond raising the alarm about childhood obesity to the implementation and evaluation of health promotion interventions aimed at obesity prevention.

\subsection{Inclusion and Exclusion Criteria}

Given that our review question sought to identify and synthesize themes across the content and protocols of various nutrition interventions, we defined our inclusion criteria using the following PICo tool (Population, Interest, Context): Population targeted in the intervention should include at least part of the 10-14-year-old age range and should not be focused on youth with eating disorders or other specific nutrition needs related to a medical condition. Interest was interventions that were (1) nutrition, diet, or food-related and (2) included a description of the process for training those delivering the intervention or for training youth within the target population to deliver nutrition content to others. Context for the interventions were an urban school or community-based setting, either in the U.S. or in a setting comparable to a U.S. urban environment. Home-based interventions were excluded.

Qualitative studies related to the development or evaluation of an intervention were included if they described participatory research with youth from the target population or if interview subjects were those participating in or delivering the intervention and if there was at least one accompanying paper describing results of the intervention. 
Given the challenges of following the same students consistently over a prolonged period of time in interventions that occur outside the classroom, papers were excluded if the intervention content was scaffolded and delivered over more than one academic year. Cross-sectional studies, review articles, book chapters, and poster abstracts were also excluded.

\subsection{Secreening and Selection Process}

Search results were uploaded to the Covidence online systematic review tool (Covidence, Melbourne, Australia), where duplicates were automatically removed by the review tool. A screening team consisting of four members worked in pairs so that two people independently screened the titles and abstracts of all articles identified through the search process and voted on inclusion or exclusion according to the criteria in the above section. The same process was followed in the full-text screening stage so that all papers were independently read and voted on for inclusion or exclusion by two screeners. At both stages, conflicts between screening team member votes were resolved by the first author. Two additional papers were added to the full-text review after the clinical trial registry for the study was identified through the systematic search process. Where multiple papers existed for the same intervention, all were included if the intervention met the inclusion criteria. Five additional papers were identified during the full-text stage that pertained to included interventions and were used in the data extraction stage.

\subsection{Data Extraction and Synthesis Approach}

Our focus on qualitative aspects of nutrition education interventions-namely trainthe-trainer process and design, intervention content and delivery, and youth receptivityled us to examine qualitative and mixed-methods approaches to synthesizing results. We sought to examine a wide variety of interventions-from those with a full nutrition education curriculum as in a classroom or a structured after-school program, to interventions that trained same-age peers to have informal conversations about nutrition, as well as scenarios in-between such as out-of-school settings led by community volunteers or young adult near-peers. We therefore set the inclusion criteria to allow for a diversity of methods, believing important themes would emerge among different types of interventions that would aid in developing new nutrition education programs with a robust training component. Based on our scoping searches, nutrition intervention expertise within the research team, and a review of qualitative synthesis methods, we selected a framework synthesis approach [14-16]. Framework synthesis is an application of the 'framework analysis' method used in primary research to systematic reviews [14]. It provides an $a$ priori scaffold for organizing and mapping data from included studies, while permitting flexibility to iterate as the data is integrated into the framework [17].

In order to describe the elements of the nutrition education interventions identified through our search process consistently, we developed an analytical framework for grouping similar settings and training audiences, and then identified commonalities within each group. We wanted to examine classroom-based and extracurricular interventions separately to compare and contrast approaches in each of these settings. We also differentiated between populations trained to deliver the intervention to determine whether training approaches, intervention design or youth receptivity varied depending on whether adults, cross-age or near peers (older than target population but under age 23), or same-age peers delivered the intervention (see Table 1 below). 
Table 1. Framework for categorizing nutrition education interventions.

\begin{tabular}{ccccc}
\hline & & & Population Trained \\
\hline \multirow{3}{*}{ Intervention Setting } & $\begin{array}{c}\text { Classroom } \\
\text { (part of school curriculum) }\end{array}$ & Adults & Cross-Age Peers & Same-Age Peers \\
\cline { 2 - 5 } & $\begin{array}{c}\text { Afterschool, extracurricular, or } \\
\text { school club activities occurring } \\
\text { outside the classroom }\end{array}$ & D & E & F \\
\hline
\end{tabular}

Once the categories A-F described above were identified, we organized the themes within each subgroup according to the following dimensions, driven by our review purpose stated previously: (1) train-the-trainer approaches, including number and duration of sessions and follow-up or support during the intervention; (2) common nutrition topics covered across the interventions; (3) format and delivery of the interventions, (4) youth receptivity, feedback, and outcomes measured; and (5) feedback and outcomes from those delivering the intervention, if assessed. All four members of the screening team extracted data independently and systematically for each of the categories and dimensions described above. The team members were once again partnered to independently extract data for each category or dimension. The lead author resolved any discrepancies in data extraction. Extracted data also included author information, funding source, study aims and location, demographic characteristics of participants, and theoretical basis for the intervention, if available.

\subsection{Quality Assessment}

Traditional methods of quality assessment used in systematic reviews do not always translate easily to qualitative reviews that include papers with a wide variety of study designs, as was the case for our review [14]. Our focus on training approaches, intervention messaging, and methods of evaluation rather than a primary emphasis on outcomes meant that the inclusion criteria allowed for a range of study types, from cluster randomized trials to protocol papers, that could not be directly compared to one another in terms of quality. While we determined that studies would not be excluded on the basis of quality due to their potential to provide information valuable to our review question, we assessed the methodological strengths and limitations of the included studies in order to consider the effect of limitations on our review findings [18]. For this assessment, we used a modified version the CASP tool for qualitative research [19]. We omitted the question asking whether qualitative methodology is appropriate, given that many of our included studies had quantitative research questions and were not designed to be assessed according to qualitative criteria. However, when the questions were applied according to the aim of each study, the tool provided a consistent framework for identifying methodological strengths and limitations. Without a definitive tool for such an assessment across a range of study types, the CASP tool was the best fit for our analysis.

We dichotomized studies into those with adequate methodological strength and those that were methodologically limited. The review team decided that studies with four or more 'no' responses using the CASP tool would be categorized as methodologically limited. Any differences in opinion in quality assessment were discussed among the review team until we reached consensus on categorization of each study. Following our review synthesis, we conducted a sensitivity analysis to determine whether the exclusion of methodologically limited studies affected the themes identified or the complexity of detail within each theme $[19,20]$.

\section{Results}

The database search yielded 2041 articles after duplicates were removed; following title and abstract screening, 88 papers were retained for full text screening. Two additional 
full text papers were added from hand searching after the intervention was identified in a clinical trial protocol captured by the database search. The screening process identified 48 papers meeting the criteria for inclusion in the review, representing 39 unique interventions. An additional five papers were identified during the full text review that pertained to included interventions, for a total of 53 papers used in the data extraction process [21-73]. The most common reasons for exclusion at the full text stage included a target population outside the 10-14-year-old age range $(n=16)$, lack of description of the training process $(n=14)$, and an intervention scaffolded over multiple school years $(n=8)$. The flowchart in Figure 1 details the screening and selection process.
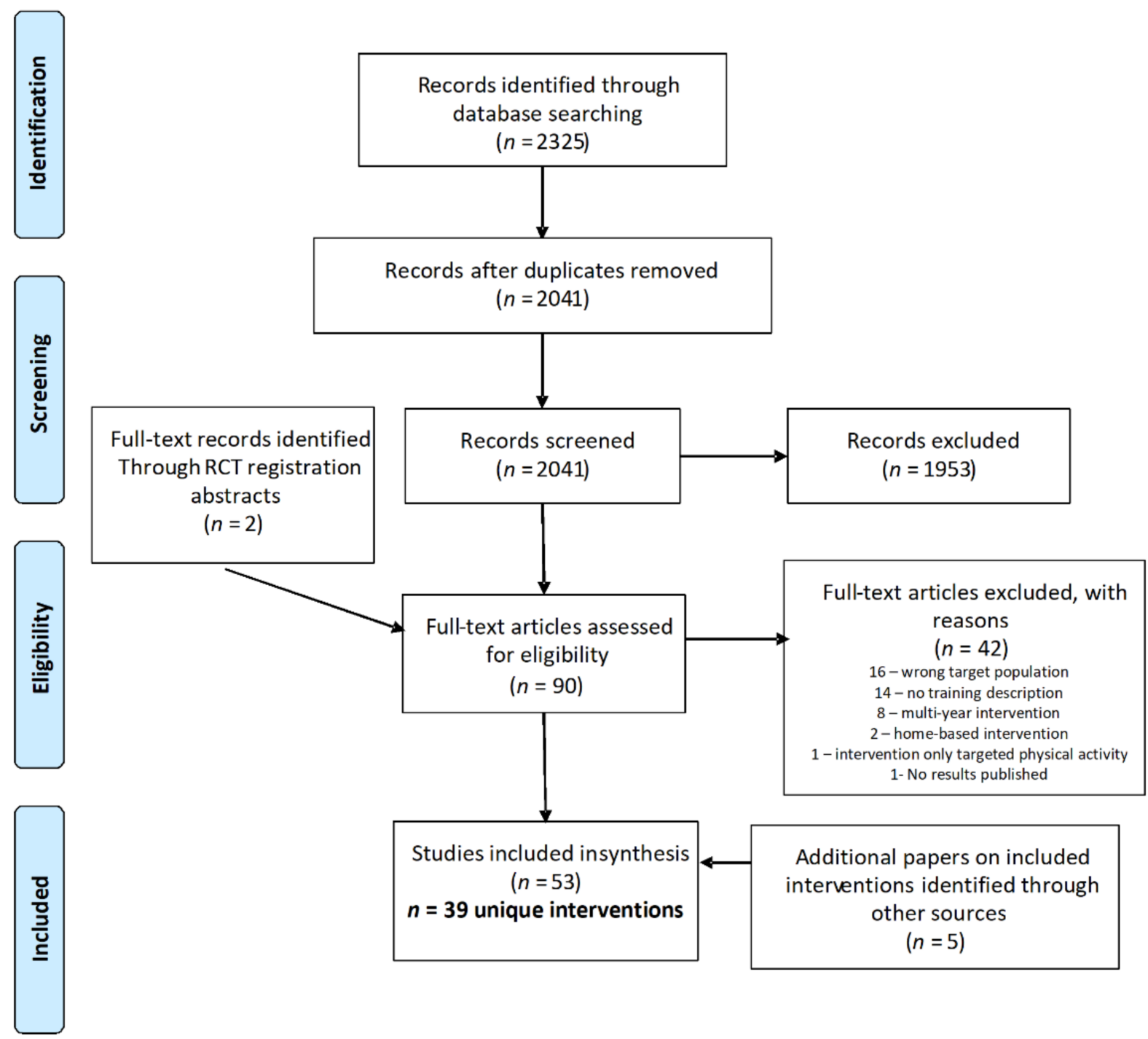

Figure 1. PRISMA flowchart of study selection process.

Of the 39 interventions included, the majority $(n=23)$ took place in the United States. Interventions outside the U.S. were in Europe $(n=7)$, Canada $(n=2)$, China $(n=2)$, and one each in Australia, New Zealand, Aruba, and Ethiopia. The framework shown in Table 1 above was applied to each of the 39 interventions to divide them into categories. Eight of the interventions $[21,40,45,52,53,59,65,70,72,73]$ included two different groups that were trained as facilitators, so they were included in both applicable categories. Two interventions $[33,46,47]$ had both an in-class curriculum component and an out-of-school component where students interacted with professional athletes; these are included in both groups A and D. Five interventions trained the target population themselves to deliver the intervention to others. These were classified into the same age peer groups since the training 
was targeted at 10-14-year-olds. The trained youth then delivered nutrition information to the community (Group F) [45,48,55,63], or taught younger students (Group C) [67].

In our quality assessment, 34 of the 39 studies were categorized as having adequate methodological strength. We observed the following limitations most commonly across included studies: (1) study design, as not all interventions could be conducted in a randomized setting or include a comparison group, (2) insufficient power to detect an intervention effect, (3) short follow-up periods that do not allow for assessment of long-term behavior change, and (4) difficulty in obtaining reliable dietary intake information from participant self-report. We conducted a sensitivity analysis by excluding the five studies identified as methodologically limited $[22,27,58,64,68]$ from the synthesis, and still identified the same themes. Although these studies made contributions toward our review question, such as incorporating the community into intervention design [22] or empowering youth to advocate in their community [58], these details were also present in other included studies. The "thickness" of the themes was not diminished when the sensitivity analysis was performed, as none of the details identified within each theme were dependent on only one study.

In the sections that follow, we identify the key themes from each of the intervention groups, and a summary table is provided for each group. We summarize the training design, intervention format and delivery, and the evaluation indicators used for each intervention, along with notable results. For outcome results, we focused on significant changes in food groups of concern for adolescents: fruit and vegetables, and sugar-sweetened beverages. We also summarized qualitative feedback from intervention participants and those delivering the intervention when it was reported in studies.

\subsection{Group A: Classroom-Based Interventions That Trained Adults}

Nutrition education interventions delivered in a classroom setting where adults were the population trained to deliver the intervention was the largest group in our categorization system ( $n=19$ unique interventions). Teachers were the primary population trained, though in some instances, graduate students, volunteers, or assistants were also trained as co-teachers $[22,49-51,54,56,57,69]$. In five of the interventions, the authors describe an initial training with follow-up trainings or regular meetings with teachers during the intervention to provide support or resolve any issues that arose [22,28-32,45-47,51]. Most trainings are described as in-services or professional development for teachers, and several note that trainings were interactive, giving teachers the opportunity to practice delivering the content to the trainers and their peers. Four interventions emphasized encouraging those delivering the intervention to tailor examples and references to the local context [22,45,49-51].

Basic nutrition concepts were covered across the interventions, e.g., energy balance, food groups, portion sizes, healthy meals, and snacks. Key messages included increasing fruit and vegetable consumption, decreasing sugar-sweetened beverage and unhealthy snack consumption, and eating out less often. Several of the interventions included activities where students learned to read nutrition labels, track their food intake, set goals, or make plans for healthy eating, assess their neighborhood food environment, and develop strategies for making healthy choices within their context.

In four of the interventions, the curriculum was incorporated into students' PE class $[21,22,46,47,72,73]$, while in two others, it was incorporated into science class and specifically mentioned an inquiry-based approach for student learning [27-33]. Eight of the interventions explicitly mentioned aligning the content with state or national standards or curriculums [27-32,34,36,37,49-51,64]. In three instances, homework was included in the intervention design that was meant to facilitate students engaging with their family about the nutrition information $[34,37,49,50]$. Four interventions also involved a connection to school meals, often engaging students in advocating for healthy meal options they would enjoy $[45,54,56,57,69]$. 
Evaluation measures varied by intervention but commonly included analysis of anthropometric changes, shifts in dietary intake, and differences in knowledge or attitudes between pre-and post-intervention. For process evaluation, six of the interventions included observations of a portion of the classroom lessons by research staff to assess fidelity and student engagement $[21,28-32,45,61,69,72,73]$. Four of the interventions held student focus groups post-intervention to gain qualitative feedback [22,27,54,69], and two used a student satisfaction survey [28-33]. Table 2 below further describes the interventions included in Group A.

\subsection{Group B: Classroom-Based Interventions That Trained Cross-Age Peers}

There were four interventions that trained cross-age peers to deliver classroom-based lessons. Three of the interventions trained high school students [21,35,38], and the remaining one trained undergraduate university students [59]. In three of the four interventions, cross-age peers taught as a group [38,59] or with teachers [19]. Two of the interventions had weekly training for cross-age peers [21,35], and two emphasized the opportunity to practice delivering the intervention as part of the training [21,38].

One of the interventions focused specifically on healthy beverages [59]; the other three all included both nutrition and physical activity content. In each of the interventions, there was an emphasis on games as a medium for delivering the nutrition content. Compared with the interventions in Group A, these interventions were delivered over a shorter period of time, except for the one where cross-age peers worked with PE teachers [21]. Role-modeling healthy habits was a key emphasis with cross-age peers.

Outcome measurers were similar to Group A, though one of the studies evaluated outcomes and intervention acceptability for the cross-age peers [38], which could serve as indicators of the engagement level of those delivering the intervention. Of note, for one intervention, only the group that received the intervention from cross-age and sameage peers showed a sustained significant decrease in SSB consumption [59]. The four interventions are described in Table 3.

\subsection{Group C: Classroom-Based Intereventions That Trained Same-Age Peers}

Two classroom-based interventions trained same-age peers as facilitators; in both cases the peers had strong support and mentorship from either adults or cross-age peers. Both interventions also put the same-age peers in groups to deliver the intervention material. In one of the interventions, those trained were in our target population age range and delivered the intervention to younger elementary students [67]. This intervention is included here and not in Group B in order to examine it alongside other trainings designed for the same age group. The training elements in these interventions provide insight into strategies for empowering the target age group, which is a key component of many nutrition education interventions for middle schoolers. Table 4 describes the interventions included in Group C. 
Table 2. Group A: Classroom-based interventions that trained adults.

\begin{tabular}{|c|c|c|c|c|c|c|}
\hline $\begin{array}{l}\text { Author, } \\
\text { Year }\end{array}$ & $\begin{array}{l}\text { Intervention Name or } \\
\text { Description }\end{array}$ & $\begin{array}{l}\text { Population } \\
\text { Characteristics: } \\
\text { Grade Level/Age } \\
\text { (Sample Size), } \\
\text { Location }\end{array}$ & $\begin{array}{l}\text { Group } \\
\text { Receiving Training }\end{array}$ & Training Design & $\begin{array}{l}\text { Intervention Frequency } \\
\text { and Duration }\end{array}$ & Evaluation Indicators and Notable Results \\
\hline $\begin{array}{l}\text { Arlinghaus, } \\
2017^{1}[21]\end{array}$ & $\begin{array}{l}\text { Obesity } \\
\text { prevention program } \\
\text { with compañeros }\end{array}$ & $\begin{array}{l}\text { 6th and } 7 \text { th grade } \\
(n=506), \\
\text { Houston, TX }\end{array}$ & PE teachers & $\begin{array}{l}\text { Teachers were trained in leading all } \\
\text { aspects of the intervention, which } \\
\text { focused on basic physical activity and } \\
\text { nutrition education. They were } \\
\text { provided with strategies for using } \\
\text { positive reinforcement and constructive } \\
\text { feedback with students. } \\
\text { Those who worked with cross-age peers } \\
\text { (see Group B) met with them regularly } \\
\text { to provide feedback and guidance. } \\
\text { Teachers met weekly with research staff } \\
\text { to discuss any issues. }\end{array}$ & $\begin{array}{l}\text { Intervention was delivered } \\
\text { during middle school } \\
\text { students' regularly } \\
\text { scheduled PE class period } \\
\text { for } 6 \text { months; } 50 \text { min a day, } \\
5 \text { days a week. One day } \\
\text { each week focused } \\
\text { specifically on healthy } \\
\text { eating. }\end{array}$ & $\begin{array}{l}\text { Outcome: } \\
\text { change in anthropometrics; only students with } \\
\text { BMI percentile at or above } 85 \% \text { at baseline } \\
(n=189) \text { were included in the analysis. } \\
\text { Process: } \\
\text { fidelity of implementation and a random } \\
\text { assessment of } 10 \% \text { of classes to record } \\
\text { frequency of positive reinforcement and } \\
\text { constructive feedback. }\end{array}$ \\
\hline $\begin{array}{l}\text { Baskin, } \\
2009[22]\end{array}$ & $\begin{array}{l}\text { Described design, } \\
\text { implementation and } \\
\text { lessons learned from a } \\
\text { pilot obesity } \\
\text { prevention program } \\
\text { implemented in a } \\
\text { low-resource school }\end{array}$ & $\begin{array}{l}7 \text { th and } 8 \text { th grade } \\
(n=113), \\
\text { Southern U.S. }\end{array}$ & $\begin{array}{l}\text { PE teachers, health } \\
\text { educator, and } \\
\text { graduate students } \\
\text { who served as teacher } \\
\text { aids during lessons }\end{array}$ & $\begin{array}{l}\text { Initial training provided when } \\
\text { curriculum was finalized. Training } \\
\text { emphasized active learning and } \\
\text { hands-on activities. } \\
\text { Researchers met quarterly with those } \\
\text { implementing the intervention to } \\
\text { address any issues that arose and } \\
\text { discuss any program modifications. }\end{array}$ & $\begin{array}{l}\text { Intervention was } \\
\text { implemented over one } \\
\text { school year. Students had a } \\
\text { health education period } \\
\text { once a week during their } \\
\text { normally scheduled 50-min } \\
\text { PE class. The curriculum } \\
\text { included food } \\
\text { demonstrations and } \\
\text { tastings. }\end{array}$ & $\begin{array}{l}\text { Outcome: changes in anthropometrics, health } \\
\text { behaviors, dietary intake, and physical fitness. } \\
\text { Process: meetings with school staff and } \\
\text { research meetings were recorded and analyzed, } \\
\text { and themes were identified. Focus groups } \\
\text { were conducted with students and staff to } \\
\text { determine acceptability. } \\
\text { Results: } \\
\text { In focus groups, students reported making } \\
\text { changes to their diet and thought the program } \\
\text { should continue and be expanded to 6th } \\
\text { graders. They enjoyed interactive games but } \\
\text { reported hesitancy to try new foods and dislike } \\
\text { of "healthier" foods in the school cafeteria. }\end{array}$ \\
\hline
\end{tabular}


Table 2. Cont.

\begin{tabular}{llll} 
Author, & Intervention Name or \\
Year & $\begin{array}{l}\text { Population } \\
\text { Characteristics: } \\
\text { Grade Level/Age } \\
\text { (Sample Size), } \\
\text { Location }\end{array}$ & $\begin{array}{l}\text { Group } \\
\text { Receiving Training }\end{array}$ & Training Design \\
\hline
\end{tabular}

2-day training focusing on the skills necessary to teach program lesson plans. During program implementation teachers completed an online lesson about fidelity and feasibility. feedback survey to provide information
Intervention Frequency and Duration

\section{Evaluation Indicators and Notable Results}

Outcome: changes in dietary behaviors,

attitudes, and frequency of eating meals with friends and family.

Results:

19-week program

addressing state educational standards for high school and intermediate school.

\begin{tabular}{lll} 
Bukhari, & Diet for a Healthy & 9th grade \\
\hline & Planet with Teen Battle & $(n=98)$,
\end{tabular}

Chefs curriculum Brooklyn, NY

Classroom teachers

Participants reported eating vegetables as

snacks significantly more often

post-intervention compared with a control group

Process: reach, focus groups with students, reflective exercises for students, dose school for a semester; class was daily for $1 \mathrm{~h}$ delivered, and feasibility and fidelity as reported by teachers.

Results:

In focus groups, students reported eating more fruits and vegetables and an increased

willingness to try new foods.

Outcome: changes in food and activity choices mediating variables measured included self-efficacy, outcome expectations, beliefs, attitudes, and perceived barriers.

Results:

A 3-h intensive professional development session was held for teachers prior to the intervention start, and a follow-up 3-h training session was held in the middle of the intervention. A research staff member also attended A research steff memberalso attended met with each teacher weekly to provide support and feedback. $n=1136$ in RCT New York, NY

Science teachers

$\begin{array}{lll}2010[28] & \text { Choice, Control and } & \begin{array}{l}(n=278 \text { in pilot; } \\ +4=1136 \text { in RCT }),\end{array} \\ \text { Change } & \text { Science teachers } \\ \text { Papers [29-32] } & & \end{array}$

Curriculum consists of 24, 45 -min, science and nutrition education lesson taught over 8-10 weeks. Some lessons were taught over multiple days for a total of 30-35 sessions.

Participants significantly decreased number of SSBs consumed and the portion size of SSBs compared to a control group. The pilot group additionally reported a significant increase in fruit and vegetable consumption, but the RCT intervention group did not.

Process: teacher professional development, teacher implementation and student reception. Results:

Curriculum aligns with national science standards.
Student engagement level was evaluated by research staff during classroom sessions and the mean was $72 \%$. Students were particularly engaged in hands-on activities. Mean student satisfaction with the program measured by survey was 2.9 on a 4 -point scale. 
Table 2. Cont.

\begin{tabular}{|c|c|c|c|c|}
\hline $\begin{array}{l}\text { Author, } \\
\text { Year }\end{array}$ & $\begin{array}{l}\text { Intervention Name or } \\
\text { Description }\end{array}$ & $\begin{array}{l}\text { Population } \\
\text { Characteristics: } \\
\text { Grade Level/Age } \\
\text { (Sample Size), } \\
\text { Location }\end{array}$ & $\begin{array}{l}\text { Group } \\
\text { Receiving Training }\end{array}$ & Training Design \\
\hline $\begin{array}{l}\text { Dubuy, } \\
2014^{2}[33]\end{array}$ & Health Scores! & $\begin{array}{l}10-14 \text { years old } \\
(n=605), \\
\text { Flanders, Belgium }\end{array}$ & Teachers & $\begin{array}{l}\text { Prior to the intervention, teachers at } \\
\text { participating schools received training } \\
\text { on a range of activities related to healthy } \\
\text { eating and physical activity. Further } \\
\text { details about the teacher training and } \\
\text { in-school curriculum were not provided } \\
\text { in the paper. } \\
\text { The key intervention strategy was using } \\
\text { professional football players as credible } \\
\text { role models for healthy lifestyle } \\
\text { behaviors (see Group D). }\end{array}$ \\
\hline
\end{tabular}

Intervention Frequency

and Duration

\section{Evaluation Indicators and Notable Results}

Outcome: changes in dietary habits, frequency of breakfast consumption, eating attitudes and self-efficacy, and physical activity levels.

Results:

Those in the intervention group increased water and vegetable consumption, and this trended toward significance compared with the control group.

cut curriculum bookended at the start and end by clinics team

the control group.

Process: youth satisfaction with professional athlete clinics, response to videos and letters and overall satisfaction with the program Results:

Youth overall satisfaction with the intervention was 7.82 out of 10, and the two intervention topics most commonly recalled by youth when asked were breakfast and vegetables.

8-week in-class and applied compulsory homework teaching module (length of a school term in New

Classroom teachers at Teachers received a half-day of training intervention schools $\quad 90$ min was spent on the benefits of 7-10 years old and a lead teacher physical activity and healthy eating for school (who were Zealand) grounded in the
national school curriculum. The in-class portion was delivered in 3 90-min students and previous strategies to delivered in 390-min sessions a week, and one integrate these topics into the permitted to curriculum. The second 90 min was spent on the program modules,

Auckland and implement the examples of implementation and an study)
Outcome: changes in physical activity, dietary patterns, screen time, and anthropometrics.

Results:

Participants had a significant increase in fruit consumption post-intervention compared with a control group, but the change was not sustained at the 6-month follow up.

Anecdotally, students seemed more engaged in the physical activity topics that nutrition ones during the intervention. the previous week's

homework.

An online portal allowed

students to share

homework-related

information with other

students, including those at

other schools. 
Table 2. Cont.

\begin{tabular}{|c|c|c|c|c|c|c|}
\hline $\begin{array}{l}\text { Author, } \\
\text { Year }\end{array}$ & $\begin{array}{l}\text { Intervention Name or } \\
\text { Description }\end{array}$ & $\begin{array}{l}\text { Population } \\
\text { Characteristics: } \\
\text { Grade Level/Age } \\
\text { (Sample Size), } \\
\text { Location }\end{array}$ & $\begin{array}{l}\text { Group } \\
\text { Receiving Training }\end{array}$ & Training Design & $\begin{array}{l}\text { Intervention Frequency } \\
\text { and Duration }\end{array}$ & Evaluation Indicators and Notable Results \\
\hline $\begin{array}{l}\text { Fahlman, } \\
2008 \text { [36] }\end{array}$ & $\begin{array}{l}\text { Michigan Model } \\
\text { "What's Food Got to } \\
\text { Do With It?" } \\
\text { curriculum }\end{array}$ & $\begin{array}{l}\text { Middle school } \\
(n=783), \\
\text { Large } \\
\text { metropolitan area } \\
\text { in Michigan }\end{array}$ & Classroom teachers & $\begin{array}{l}8 \mathrm{~h} \text { of in-service training was held on the } \\
\text { curriculum and the textbook, "What's } \\
\text { Food Got to Do With It?" }\end{array}$ & $\begin{array}{l}\text { 8-session nutrition module } \\
\text { that is part of larger } \\
\text { statewide health curriculum } \\
\text { for middle school taught } \\
\text { over the course of } 1 \text { month. }\end{array}$ & $\begin{array}{l}\text { Outcome: changes in dietary intake, nutrition } \\
\text { knowledge, and healthy eating efficacy } \\
\text { expectations. } \\
\text { Results: } \\
\text { Participants significantly increased } \\
\text { consumption of fruits and vegetables } \\
\text { post-intervention compared with a control } \\
\text { group. Of note, about one-third of the initial } \\
\text { sample was lost to follow-up. }\end{array}$ \\
\hline $\begin{array}{l}\text { Fairclough, } \\
2013 \text { [37] }\end{array}$ & $\begin{array}{l}\text { Children's Health, } \\
\text { Activity and Nutrition: } \\
\text { Get Educated! } \\
\text { (CHANGE!) }\end{array}$ & $\begin{array}{l}10-11 \text { years old } \\
(n=318), \\
\text { Wigan, England }\end{array}$ & Year 6 Teachers & $\begin{array}{l}\text { A 4-h training was provided to teachers } \\
\text { in delivering the curriculum. }\end{array}$ & $\begin{array}{l}\text { 20-week curriculum with } \\
\text { weekly } 60 \text {-minue classroom } \\
\text { sessions that were aligned } \\
\text { with the national primary } \\
\text { school curriculum. Also } \\
\text { included homework tasks. }\end{array}$ & $\begin{array}{l}\text { Outcome: changes in anthropometrics, } \\
\text { physical activity, sedentary time, and food } \\
\text { intake. }\end{array}$ \\
\hline $\begin{array}{l}\text { Heo, } \\
2018^{3}[45]\end{array}$ & HealthCorps & $\begin{array}{l}\text { High school } \\
(n=832), \\
\text { New York, NY }\end{array}$ & $\begin{array}{l}\text { Program coordinator } \\
\text { at each school teaches } \\
\text { lessons, oversees } \\
\text { program activities, } \\
\text { and serves as a } \\
\text { mentor for students } \\
\text { Extra- } \\
\text { curricular activities } \\
\text { also develop youth } \\
\text { from the target } \\
\text { population as peer } \\
\text { leaders (see Group F) }\end{array}$ & $\begin{array}{l}\text { Coordinators receive three weeks of } \\
\text { HealthCorps training over the summer } \\
\text { as well as a week of professional } \\
\text { development over the winter break. } \\
\text { Coordinators also have weekly check-ins } \\
\text { with program supervisors and at least } \\
\text { one site visit from the program } \\
\text { supervisor during the school year. }\end{array}$ & $\begin{array}{l}10 \text { classroom lessons are } \\
\text { delivered as part of the } \\
\text { curriculum. Were delivered } \\
\text { over the course of a } \\
\text { semester or school year, } \\
\text { depending on the school. } \\
\text { For students participating } \\
\text { in program activities } \\
\text { outside the classroom, total } \\
\text { exposure could be up to } 45 \\
\text { h over } 36 \text { weeks. }\end{array}$ & $\begin{array}{l}\text { Outcome: changes in anthropometrics, } \\
\text { knowledge, and health behavior. } \\
\text { Results: } \\
\text { Students participating in HealthCorps } \\
\text { significantly increased fruit and vegetable } \\
\text { intake; } \\
\text { there was no change in the control group. } \\
\text { Process: site visit by program supervisor to } \\
\text { ensure fidelity. }\end{array}$ \\
\hline
\end{tabular}


Table 2. Cont.

\begin{tabular}{|c|c|c|c|c|c|c|}
\hline $\begin{array}{l}\text { Author, } \\
\text { Year }\end{array}$ & $\begin{array}{l}\text { Intervention Name or } \\
\text { Description }\end{array}$ & $\begin{array}{l}\text { Population } \\
\text { Characteristics: } \\
\text { Grade Level/Age } \\
\text { (Sample Size), } \\
\text { Location }\end{array}$ & $\begin{array}{l}\text { Group } \\
\text { Receiving Training }\end{array}$ & Training Design & $\begin{array}{l}\text { Intervention Frequency } \\
\text { and Duration }\end{array}$ & Evaluation Indicators and Notable Results \\
\hline $\begin{array}{l}\text { Irwin, } \\
2012^{2}[46] \\
+1 \text { paper }[47]\end{array}$ & $\begin{array}{l}\text { Get Fit with the } \\
\text { Grizzlies }\end{array}$ & $\begin{array}{l}\text { 4th and 5th grade } \\
(n=888), \\
\text { Memphis, TN }\end{array}$ & PE teachers & $\begin{array}{l}\text { Teachers attended a half-day training } \\
\text { workshop on the 6-week curriculum and } \\
\text { the support services that were available } \\
\text { to them to implement the curriculum } \\
\text { (included web support and special } \\
\text { activities with the Memphis Grizzlies } \\
\text { NBA team-see Group D). Teachers } \\
\text { were also trained to administer the pre } \\
\text { and post-tests for the intervention. } \\
\text { Each teacher also received two } \\
\text { one-on-one follow-up trainings at their } \\
\text { school during the intervention. }\end{array}$ & $\begin{array}{l}\text { 6-week mini-unit } \\
\text { incorporated into PE } \\
\text { curriculum; one lesson } \\
\text { taught per week. Players, } \\
\text { dancers and/or the mascot } \\
\text { for the Memphis Grizzlies } \\
\text { visited the schools for an } \\
\text { assembly, and there was a } \\
\text { district-wide Get Fit with } \\
\text { the Grizzlies Achievement } \\
\text { Day at Grizzlies home arena } \\
\text { at the end of the program. }\end{array}$ & $\begin{array}{l}\text { Outcome: changes in knowledge, eating } \\
\text { behaviors, and physical activity habits. } \\
\text { Results: } \\
\text { Daily fruit servings increased significantly } \\
\text { from pre to post- } \\
\text { intervention. }\end{array}$ \\
\hline $\begin{array}{l}\text { Kipping, } \\
2014 \text { [49] } \\
+1 \text { paper [50] }\end{array}$ & $\begin{array}{l}\text { Active for Life } \\
\text { Year } 5 \text { (AFLY5) } \\
\text { (Adapted from Planet } \\
\text { Health and Eat Well, } \\
\text { Keep Moving } \\
\text { interventions } \\
\text { in the U.S.) }\end{array}$ & $\begin{array}{l}\text { 9-10 years old } \\
(n=2221), \\
\text { Bristol City and } \\
\text { North Somerset, } \\
\text { England }\end{array}$ & $\begin{array}{l}\text { Year } 5 \text { classroom } \\
\text { teachers and learning } \\
\text { support assistants }\end{array}$ & $\begin{array}{l}\text { The training was } 8-9 \text { h over the course } \\
\text { of } 1 \text { day in a location away from school. } \\
\text { During the training, the intervention } \\
\text { rationale was explained, lessons and } \\
\text { homework activities in the curriculum } \\
\text { were discussed and taught by the } \\
\text { trainers interactively. Teachers and } \\
\text { assistants also had the opportunity to } \\
\text { ask questions. At the training, teachers } \\
\text { were given freedom to adapt materials } \\
\text { to their style and the range of abilities } \\
\text { for their students, but all of the } \\
\text { knowledge and skills from the } \\
\text { curriculum could be imparted. }\end{array}$ & $\begin{array}{l}\text { The curriculum consisted of } \\
16 \text { in-class lessons with } \\
10 \text { parent-child interactive } \\
\text { homework activities, } \\
\text { delivered over a period of } \\
6-7 \text { months (two out of } \\
\text { three school terms). }\end{array}$ & $\begin{array}{l}\text { Outcome: changes in physical activity, screen } \\
\text { time, food consumption, and anthropometrics. } \\
\text { Results: } \\
\text { Participants showed a significant decrease in } \\
\text { energy drink consumption post-intervention } \\
\text { compared with a control group. }\end{array}$ \\
\hline
\end{tabular}


Table 2. Cont.

\begin{tabular}{|c|c|c|c|c|c|c|}
\hline $\begin{array}{l}\text { Author, } \\
\text { Year }\end{array}$ & $\begin{array}{l}\text { Intervention Name or } \\
\text { Description }\end{array}$ & $\begin{array}{l}\text { Population } \\
\text { Characteristics: } \\
\text { Grade Level/Age } \\
\text { (Sample Size), } \\
\text { Location } \\
\end{array}$ & $\begin{array}{l}\text { Group } \\
\text { Receiving Training }\end{array}$ & Training Design & $\begin{array}{l}\text { Intervention Frequency } \\
\text { and Duration }\end{array}$ & Evaluation Indicators and Notable Results \\
\hline $\begin{array}{l}\text { Koch, } \\
2019 \text { [51] }\end{array}$ & $\begin{array}{l}\text { Food, Health, } \\
\text { \& Choices }\end{array}$ & $\begin{array}{l}\text { 5th grade } \\
(n=1159), \\
\text { New York, NY } \\
\text { (North Manhattan } \\
\text { and South Bronx) }\end{array}$ & $\begin{array}{l}\text { Classroom teachers } \\
\text { and graduate student } \\
\text { "curriculum } \\
\text { instructors" }\end{array}$ & $\begin{array}{l}\text { Teachers received a stipend to attend a } \\
\text { 6-h professional development workshop } \\
\text { the week before school began. The } \\
\text { workshop provided an overview of the } \\
\text { intervention, and teachers had the } \\
\text { opportunity to practice intervention } \\
\text { activities. } \\
\text { Curriculum instructors attended the } \\
\text { professional development with the } \\
\text { teachers, and had an additional 2-h } \\
\text { training on the intervention, and weekly } \\
\text { 2-h meetings with the research staff } \\
\text { during the intervention. } \\
\text { Classroom teachers and curriculum } \\
\text { instructors co-taught the lessons. }\end{array}$ & $\begin{array}{l}23 \text { lessons replacing } \\
2 \text { mandated units in the } \\
\text { science curriculum, } \\
\text { delivered over } 10 \text { months. } \\
\text { September-November was } \\
2 \text { lessons per week, } \\
\text { December to April was } \\
1 \text { lesson per month (due to } \\
\text { standardized testing } \\
\text { preparation), and May was } \\
2 \text { lessons per week. }\end{array}$ & $\begin{array}{l}\text { Outcome: changes in anthropometrics, dietary } \\
\text { intake, outcome expectations, self-efficacy, } \\
\text { behavioral intention, habit strength, } \\
\text { goal-setting skills, competence, and motivation. } \\
\text { Results: } \\
\text { A wellness component was delivered in some } \\
\text { schools that included a policy around foods } \\
\text { that could be served during classroom } \\
\text { activities. Students who received only the } \\
\text { wellness intervention showed a significant } \\
\text { decrease in SSB intake, but those who received } \\
\text { the curriculum only or the curriculum and } \\
\text { wellness together did not. }\end{array}$ \\
\hline $\begin{array}{l}\text { Lepe, } \\
2019[53]\end{array}$ & $\begin{array}{l}\text { Empowering Urban } \\
\text { School Children to } \\
\text { Increase Fruit and } \\
\text { Vegetable } \\
\text { Consumption Through } \\
\text { EFNEP-Enhanced PSE } \\
\text { Interventions } \\
\text { (EMPOWER) }\end{array}$ & $\begin{array}{l}\text { 5th grade } \\
(n=312), \\
\text { Pawtucket, RI }\end{array}$ & $\begin{array}{l}\text { School health } \\
\text { teachers and EFNEP } \\
\text { para- } \\
\text { professional } \\
\text { educators }\end{array}$ & $\begin{array}{l}\text { Teachers were trained in the Fresh Fruit } \\
\text { and Vegetable Program (FFVP) nutrition } \\
\text { education curriculum by SNAP-Ed staff. } \\
\text { EFENEP educators received } 22 \text {-h } \\
\text { training sessions on the Policy, Systems, } \\
\text { and Environment (PSE) curriculum they } \\
\text { would be delivering to students. Their } \\
\text { training also included an in-depth } \\
\text { orientation to process evaluation } \\
\text { methods. }\end{array}$ & $\begin{array}{l}\text { 10 30-min PSE lessons to be } \\
\text { delivered every other week } \\
\text { by trained EFNEP staff, } \\
\text { designed to augment the } \\
\text { 8-week FFVP curriculum } \\
\text { taught by classroom } \\
\text { teachers. }\end{array}$ & $\begin{array}{l}\text { Outcome: changes in knowledge and fruit and } \\
\text { vegetable consumption. } \\
\text { Process: fidelity, dose delivered, dose received, } \\
\text { reach, and program perception. } \\
\text { Results: } \\
\text { In focus groups, students reported asking for } \\
\text { more fruits and vegetables at home, and school } \\
\text { staff affirmed growth in student } \\
\text { empowerment. Mis- } \\
\text { communication between teachers and EFNEP } \\
\text { educators was identified as a barrier to } \\
\text { implementation. }\end{array}$ \\
\hline
\end{tabular}


Table 2. Cont.

\begin{tabular}{|c|c|c|c|c|c|c|}
\hline $\begin{array}{l}\text { Author, } \\
\text { Year }\end{array}$ & $\begin{array}{l}\text { Intervention Name or } \\
\text { Description }\end{array}$ & $\begin{array}{l}\text { Population } \\
\text { Characteristics: } \\
\text { Grade Level/Age } \\
\text { (Sample Size), } \\
\text { Location }\end{array}$ & $\begin{array}{l}\text { Group } \\
\text { Receiving Training }\end{array}$ & Training Design & $\begin{array}{l}\text { Intervention Frequency } \\
\text { and Duration }\end{array}$ & Evaluation Indicators and Notable Results \\
\hline $\begin{array}{l}\mathrm{Li}, \\
2010[56] \\
+1 \text { paper [57] }\end{array}$ & $\begin{array}{l}\text { The nutrition-based } \\
\text { comprehensive } \\
\text { intervention study on } \\
\text { childhood obesity in } \\
\text { China (NISCOC) }\end{array}$ & $\begin{array}{l}\text { 6-13 years old } \\
(n=9867), \\
\text { Shanghai, } \\
\text { Chongqing, } \\
\text { Guangzhou, Jinan, } \\
\text { Harbin, and } \\
\text { Beijing, China }\end{array}$ & $\begin{array}{l}\text { Teachers, classroom } \\
\text { tutors, and health } \\
\text { educators }\end{array}$ & $\begin{array}{l}\text { A 2-day training was held for the school } \\
\text { staff that would be implementing the } \\
\text { intervention. The training covered } \\
\text { integrating the program into the school } \\
\text { curriculum and performing the } \\
\text { intervention activities. Teachers } \\
\text { practiced the lessons during the training } \\
\text { to ensure understanding. }\end{array}$ & $\begin{array}{l}\text { The intervention took place } \\
\text { over } 2 \text { semesters and } \\
\text { included } 6 \text { nutrition lectures } \\
\text { that lasted a minimum of } \\
40 \text { min. A cartoon-style } \\
\text { nutrition handbook was } \\
\text { developed for the students } \\
\text { that was to be used along } \\
\text { with the lectures. }\end{array}$ & $\begin{array}{l}\text { Outcome: changes in anthropometrics, glucose } \\
\text { and lipid profiles, attitudes, knowledge, and } \\
\text { nutrition practices. }\end{array}$ \\
\hline $\begin{array}{l}\text { Mihas, } \\
2010[61]\end{array}$ & $\begin{array}{l}\text { Vyronas Youth } \\
\text { Regarding Obesity, } \\
\text { Nutrition, and } \\
\text { Attitudinal Styles } \\
\text { (VYRONAS) }\end{array}$ & $\begin{array}{l}\text { 12-13 years old } \\
(n=191), \\
\text { Athens, Greece }\end{array}$ & $\begin{array}{l}\text { Home economics } \\
\text { teachers }\end{array}$ & $\begin{array}{l}\text { Teachers attended two 3-h training } \\
\text { seminars to learn about the objectives of } \\
\text { the program, their role in delivering the } \\
\text { intervention, and the importance of } \\
\text { incorporating health and nutrition into } \\
\text { the curriculum. }\end{array}$ & $\begin{array}{l}\text { 12 1-h lessons were } \\
\text { delivered in the classroom } \\
\text { over a period of } 12 \text { weeks. } \\
\text { Teachers were supervised } \\
\text { by a health visitor or family } \\
\text { doctor from the community } \\
\text { when delivering the lessons. } \\
\text { Two meetings were also } \\
\text { held for parents providing } \\
\text { information about healthy } \\
\text { dietary habits for children. }\end{array}$ & $\begin{array}{l}\text { Outcome: changes in anthropometrics and } \\
\text { dietary intake. } \\
\text { Results: } \\
\text { Participants showed a significant increase in } \\
\text { fruit consumption post-intervention compared } \\
\text { with a control group, and this increase was } \\
\text { sustained } 12 \text { months after the intervention. }\end{array}$ \\
\hline $\begin{array}{l}\text { Olivares, } \\
2005 \text { [64] }\end{array}$ & $\begin{array}{l}\text { The program sought to } \\
\text { design and validate } \\
\text { appropriate nutrition } \\
\text { education materials for } \\
\text { Chilean primary } \\
\text { school students and } \\
\text { develop and validate a } \\
\text { teacher training } \\
\text { program that could be } \\
\text { replicated throughout } \\
\text { the country. }\end{array}$ & $\begin{array}{l}\text { 3rd-7th grade, } \\
(n=1701), \\
\text { Chile (intervention } \\
\text { was implemented } \\
\text { in schools } \\
\text { throughout the } \\
\text { country) }\end{array}$ & Classroom teachers & $\begin{array}{l}\text { Participants received } 3 \text { days of training } \\
\text { on the newly developed curriculum, } \\
\text { which included a textbook, teacher's } \\
\text { guide, and practical guides for students } \\
\text { that accompanied each of the modules. } \\
\text { Some teachers who were particularly } \\
\text { motivated by the training spontaneously } \\
\text { trained colleagues when they returned } \\
\text { to their respective schools. }\end{array}$ & $\begin{array}{l}\text { The lessons were } \\
\text { implemented over a period } \\
\text { of } 5 \text { months. }\end{array}$ & $\begin{array}{l}\text { Outcome: changes in knowledge and } \\
\text { dietary intake. } \\
\text { Results: } \\
\text { Fruit and vegetable intake increased } \\
\text { significantly among 10-11-year-old girls } \\
\text { compared to a matching control group. SSB } \\
\text { intake increased significantly among } \\
\text { 8-9-year-olds in both the intervention and } \\
\text { control groups. } \\
\text { Process: teacher feedback on program } \\
\text { perception. } \\
\text { Results: } \\
\text { Students were most engaged in activities } \\
\text { where they prepared healthy foods. }\end{array}$ \\
\hline
\end{tabular}


Table 2. Cont.

\begin{tabular}{|c|c|c|c|c|c|c|}
\hline $\begin{array}{l}\text { Author, } \\
\text { Year }\end{array}$ & $\begin{array}{l}\text { Intervention Name or } \\
\text { Description }\end{array}$ & $\begin{array}{l}\text { Population } \\
\text { Characteristics: } \\
\text { Grade Level/Age } \\
\text { (Sample Size), } \\
\text { Location }\end{array}$ & $\begin{array}{l}\text { Group } \\
\text { Receiving Training }\end{array}$ & Training Design & $\begin{array}{l}\text { Intervention Frequency } \\
\text { and Duration }\end{array}$ & Evaluation Indicators and Notable Results \\
\hline $\begin{array}{l}\text { Tsai, } \\
2009 \text { [69] }\end{array}$ & TAKE 10! & $\begin{array}{l}\text { K-6th grade } \\
(n=840), \\
\text { Chicago, IL }\end{array}$ & $\begin{array}{l}\text { Teachers and a } \\
\text { full-time volunteer }\end{array}$ & $\begin{array}{l}\text { The training oriented the teachers and } \\
\text { volunteer to the curriculum, provided } \\
\text { strategies for integrating it into their } \\
\text { other lessons, and connected health with } \\
\text { academic learning. }\end{array}$ & $\begin{array}{l}\text { The intervention was } \\
\text { implemented over the } \\
\text { course of a school year. } \\
\text { Content was adapted to be } \\
\text { appropriate for each grade } \\
\text { level. The program includes } \\
\text { daily 10-min physical } \\
\text { activity breaks in the } \\
\text { classroom and incorporates } \\
\text { nutrition information into } \\
\text { these breaks. }\end{array}$ & $\begin{array}{l}\text { Outcome: changes in anthropometrics and } \\
\text { nutrition and physical activity knowledge. } \\
\text { Process: } \\
\text { program perception evaluated through } \\
\text { observations of the sessions and interviews } \\
\text { with teachers and students at the end of the } \\
\text { intervention. Results: } \\
\text { Teachers were generally positive about the } \\
\text { program and implemented } 3-5 \text { of the sessions } \\
\text { per week. } \\
\text { Students reported better concentration after } \\
\text { moving during the sessions and recalled } \\
\text { nutrition information they learned in the } \\
\text { post-intervention interviews. }\end{array}$ \\
\hline $\begin{array}{l}\text { Tucker, } \\
2015^{2}[70]\end{array}$ & $\begin{array}{l}\text { Let's Go } 5-2-1-0 \\
\text { childhood obesity } \\
\text { prevention } \\
\text { intervention delivered } \\
\text { by school nurses plus } \\
\text { 1:1 or small group } \\
\text { coaching by nursing } \\
\text { students }\end{array}$ & $\begin{array}{l}\text { 4th and } 5 \text { th grade } \\
(n=72) \text {, } \\
\text { Location not } \\
\text { specified; } \\
\text { corresponding } \\
\text { author affiliated } \\
\text { with University of } \\
\text { Iowa }\end{array}$ & $\begin{array}{l}\text { School nurses } \\
\text { Intervention also } \\
\text { included nursing } \\
\text { students as mentors } \\
\text { (see Group D) }\end{array}$ & $\begin{array}{l}\text { Training for school nurses on delivering } \\
\text { the classroom portion of the intervention } \\
\text { was not described in the paper. }\end{array}$ & $\begin{array}{l}\text { School nurses delivered the } \\
\text { Let's Go 5-2-1-0 curriculum } \\
\text { weekly during classroom } \\
\text { instructional time in } \\
10-15 \text { increments. Dosage } \\
\text { varied from } 14-21 \text { sessions. } \\
\text { Nursing students had lunch } \\
\text { with their assigned } \\
\text { student/students weekly to } \\
\text { discuss curriculum content } \\
\text { and set health goals. }\end{array}$ & $\begin{array}{l}\text { Outcome: changes in anthropometrics, } \\
\text { physical activity levels, nutrition, family eating } \\
\text { patterns and screen time. } \\
\text { Results: } \\
\text { Self-reported daily servings of fruits and } \\
\text { vegetables increased significantly at } \\
\text { both schools. }\end{array}$ \\
\hline $\begin{array}{l}\text { Zhou, } \\
2019^{2}[72] \\
+1 \text { paper [73] }\end{array}$ & $\begin{array}{l}\text { Chinese Childhood } \\
\text { Health, Activity and } \\
\text { Motor Performance } \\
\text { Study (Chinese } \\
\text { CHAMPS) with both } \\
\text { in-school and } \\
\text { afterschool } \\
\text { components }\end{array}$ & $\begin{array}{l}\text { 7th grade } \\
(n=680), \\
\text { Beijing, Wuhu, } \\
\text { and Weifang, } \\
\text { China }\end{array}$ & $\begin{array}{l}\text { PE teachers } \\
\text { Intervention also } \\
\text { included afterschool } \\
\text { program staff (see } \\
\text { Group D) }\end{array}$ & $\begin{array}{l}\text { 2-day training focusing on adolescent } \\
\text { growth and development, designing } \\
\text { age-appropriate physical activities, and } \\
\text { instructional methods. Training } \\
\text { facilitators demonstrated activities, and } \\
\text { staff then had the opportunity to } \\
\text { practice. }\end{array}$ & $\begin{array}{l}\text { 8-month intervention; the } \\
\text { in-school portion increased } \\
\text { PE class to } 3 \text { days / week } \\
\text { and implemented daily } \\
\text { recess. As part of PE, } \\
\text { students received fitness } \\
\text { and nutrition education and } \\
\text { bi-weekly text messages. }\end{array}$ & $\begin{array}{l}\text { Outcome: Changes in physical fitness, } \\
\text { anthropometrics, cognitive function, food } \\
\text { habits and preferences, knowledge, physical } \\
\text { activity } \\
\text { Process: fidelity and dose received through } \\
\text { periodic monitoring of sessions by } \\
\text { research staff. }\end{array}$ \\
\hline
\end{tabular}

${ }^{1}$ Also included in Group B. ${ }^{2}$ Also included in Group D. ${ }^{3}$ Also included in Group F. 
Table 3. Group B: Classroom-based interventions that trained cross-age peers.

\begin{tabular}{|c|c|c|c|c|c|c|}
\hline $\begin{array}{l}\text { Author, } \\
\text { Year }\end{array}$ & $\begin{array}{l}\text { Intervention Name or } \\
\text { Description }\end{array}$ & $\begin{array}{l}\text { Population } \\
\text { Characteristics: } \\
\text { Grade Level/Age } \\
\text { (Sample Size), } \\
\text { Location }\end{array}$ & $\begin{array}{l}\text { Group Receiving } \\
\text { Training }\end{array}$ & Training Design & $\begin{array}{l}\text { Intervention Frequency } \\
\text { and Duration }\end{array}$ & $\begin{array}{l}\text { Evaluation Indicators and } \\
\text { Notable Results }\end{array}$ \\
\hline $\begin{array}{l}\text { El Rayess, } \\
2017 \text { [35] }\end{array}$ & Mark, Set, Go! & $\begin{array}{l}5 \text { th and } 6 \text { th grade } \\
(n=954), \\
\text { Providence, RI }\end{array}$ & $\begin{array}{l}\text { High school students in } \\
\text { an experiential learning } \\
\text { program that includes } \\
\text { community internships }\end{array}$ & $\begin{array}{l}\text { Cross-peers received an orientation and } \\
\text { weekly training session. Training } \\
\text { covered classroom management, small } \\
\text { group teaching strategies, and a review } \\
\text { of the material. }\end{array}$ & $\begin{array}{l}\text { 9-week program } \\
\text { (frequency of lessons } \\
\text { not specified) }\end{array}$ & $\begin{array}{l}\text { Outcome: changes in knowledge, } \\
\text { dietary behaviors, anthropometrics, } \\
\text { and physical activity } \\
\text { Results: } \\
\text { There was a significant decrease in the } \\
\text { percentage of students reporting } \\
\text { drinking soft drinks and juice at least } \\
\text { once a day. In subgroup analysis, there } \\
\text { was a significant decrease in both } \\
\text { categories for girls and for students } \\
\text { with overweight or obesity. }\end{array}$ \\
\hline
\end{tabular}


Table 3. Cont.

\begin{tabular}{|c|c|c|c|c|}
\hline $\begin{array}{l}\text { Author, } \\
\text { Year }\end{array}$ & $\begin{array}{l}\text { Intervention Name or } \\
\text { Description }\end{array}$ & $\begin{array}{l}\text { Population } \\
\text { Characteristics: } \\
\text { Grade Level/Age } \\
\text { (Sample Size), } \\
\text { Location }\end{array}$ & $\begin{array}{l}\text { Group Receiving } \\
\text { Training }\end{array}$ & Training Design \\
\hline $\begin{array}{l}\text { Foley, } \\
2017[38]\end{array}$ & $\begin{array}{l}\text { Students As LifeStyle } \\
\text { Activists (SALSA) }\end{array}$ & $\begin{array}{l}\text { Year } 8 \text { (same as U.S. 8th } \\
\text { grade) } \\
\text { *Focus of the study was } \\
\text { the cross-age peers; } \\
\text { subject number for year } \\
8 \text { students not available. } \\
\text { Western Sydney, } \\
\text { Australia }\end{array}$ & $\begin{array}{l}\text { Year } 10 \text { students } \\
(n=415)\end{array}$ & $\begin{array}{l}\text { Cross-age peers were trained by } \\
\text { university students from health and } \\
\text { education disciplines who worked } \\
\text { themselves had received educator } \\
\text { training from the project staff. } \\
\text { The Year } 10 \text { students were trained to } \\
\text { deliver the intervention in a one-day } \\
\text { workshop and were given a scripted } \\
\text { manual to use as a guide for delivering } \\
\text { the intervention. As part of the training, } \\
\text { students practiced delivering the lessons } \\
\text { in front of one another. }\end{array}$ \\
\hline
\end{tabular}

Intervention Frequency Evaluation Indicators and

and Duration

Notable Results

Outcomes for cross-age peers: changes in dietary behaviors, physical activity, screen time and intention to change. Results:

Four 70-min lessons delivered to a Year 8 class by a small group of $4-6$ proportion was mendations for daily fruit and vegetable intake and drinking less
than 1 cup of sugary beverages dail Process: acceptability among cross-age peers Results:

$91 \%$ would recommend the program to their peers; goal setting, leadership and teaching emerged as important themes, and $42 \%$ discussed program themes at home.

Outcome: changes in beverage intake, knowledge, and attitudes.

Results:

Significant decrease in SSB intake post-intervention, sustained through 3-month follow up among group with
Two-week training intensive that oriented the cross-age peers to the content and also aimed to build $\begin{array}{lll}\text { Lo, } & \text { Fluids Used Effectively } & \text { Grade } 9 \\ (n=113),\end{array}$ for Living (FUEL) Saskatchewan, Canada

also provided leadership for the worked with same-age

peers from the target

population, see Group C) 5-min session each week cross-age and same-age pers (three other comparison groups without pee educators did not show

significant change).

Process: participant satisfaction with content and delivery of the program. Results:

$71 \%$ enjoyed the intervention and $77 \%$ would suggest it to others.

${ }^{1}$ Also included in Group A. ${ }^{2}$ Also included in Group C. 
Table 4. Group C: Classroom-based interventions that trained same-age peers.

\begin{tabular}{|c|c|c|c|c|c|c|}
\hline $\begin{array}{l}\text { Author, } \\
\text { Year }\end{array}$ & $\begin{array}{l}\text { Intervention Name or } \\
\text { Description }\end{array}$ & $\begin{array}{l}\text { Population } \\
\text { Characteristics: } \\
\text { Grade Level/Age } \\
\text { (Sample Size), } \\
\text { Location }\end{array}$ & $\begin{array}{l}\text { Group Receiving } \\
\text { Training }\end{array}$ & Training Design & $\begin{array}{l}\text { Intervention Frequency } \\
\text { and Duration }\end{array}$ & $\begin{array}{l}\text { Evaluation Indicators } \\
\text { and Notable Results }\end{array}$ \\
\hline $\begin{array}{l}\text { Lo, } \\
2008^{1}[59]\end{array}$ & $\begin{array}{l}\text { Fluids Used Effectively for } \\
\text { Living (FUEL) }\end{array}$ & $\begin{array}{l}\text { Grade } 9 \\
(n=113), \\
\text { Saskatchewan, Canada }\end{array}$ & $\begin{array}{l}\text { Same-age, Grade } 9 \text { peers } \\
\text { (worked with cross-age } \\
\text { peers, see Group B) }\end{array}$ & $\begin{array}{l}\text { Had their own two-week } \\
\text { training intensive to orient them } \\
\text { to the content and build } \\
\text { teamwork. They were } \\
\text { connected to cross-age peers } \\
\text { for guidance. }\end{array}$ & $\begin{array}{l}\text { Six-week program, one } \\
\text { 45-min session } \\
\text { each week }\end{array}$ & $\begin{array}{l}\text { Outcome: changes in } \\
\text { beverage intake, } \\
\text { knowledge, } \\
\text { and attitudes } \\
\text { Process: participant } \\
\text { satisfaction with content } \\
\text { and delivery of } \\
\text { the program. } \\
\text { See Table } 2 \text { for results }\end{array}$ \\
\hline $\begin{array}{l}\text { Stock, } \\
2007[67]\end{array}$ & Healthy Buddies & $\begin{array}{l}4 \text { th- } 7 \text { th grade } \\
(n=199) \\
\text { British Columbia, Canada }\end{array}$ & $\begin{array}{l}\text { Cross-age peers. In this } \\
\text { case, the students in the } \\
\text { target age range for the } \\
\text { study were the older } \\
\text { peers }\end{array}$ & $\begin{array}{l}\text { Cross-age peers received a } \\
\text { lesson from the intervention } \\
\text { teacher once a week and then } \\
\text { taught that lesson to their } \\
\text { younger "buddies" that same } \\
\text { week. Older students still } \\
\text { developing leadership skills } \\
\text { were paired with another older } \\
\text { student with strong leadership } \\
\text { ability. }\end{array}$ & $\begin{array}{l}21 \text { weeks-the cross-age } \\
\text { peers receive }(45 \mathrm{~min}) \\
\text { and then deliver }(30 \mathrm{~min}) \\
\text { a lesson once per week. } \\
\text { Paired classes also had } \\
\text { two } 30 \text {-min structured } \\
\text { physical activity sessions } \\
\text { together weekly. }\end{array}$ & $\begin{array}{l}\text { Outcome: changes in } \\
\text { height, weight, blood } \\
\text { pressure, and heart rate; } \\
\text { 9-min run, knowledge of } \\
\text { nutrition and physical } \\
\text { activity, and eating } \\
\text { and physical } \\
\text { activity behaviors. }\end{array}$ \\
\hline
\end{tabular}




\subsection{Group D: Community, Afterschool, or Extracurricular Interventions That Trained Adults}

Ten interventions trained adults to deliver nutrition education in a context outside the classroom: four were based in the community $[33,46,47,58,62]$, four were afterschool programs $[40,60,71-73]$, one was delivered in multiple settings that included both community and afterschool programs [52,53], and one took place during school lunch [70]. Four of the interventions also included classroom-based components [33,46,47,70,72,73].

The types of interventions varied widely, as did the training format, but a common theme across all the interventions in this group was an expansion beyond basic nutrition education. Four of the interventions particularly emphasized role models/mentors [33,46,47,58,70]; two of which included activities with professional sports teams in the community. Interventions in this group also went deeper into the food environment, food sources, student advocacy for healthy changes, and addressing barriers to healthy eating than did the interventions that were classroom- based. In terms of evaluation, two interventions used student surveys to measure acceptability $[33,52,53]$, and two conducted focus groups with youth to assess barriers and facilitators to healthy eating $[60,62]$. Of note in these focus groups with youth in different parts of the U.S.: both groups expressed limited availability of healthy food in their home and neighborhood environments as a major limiting factor in healthy eating, especially when it came to fresh fruit and vegetables. The interventions included in Group D are presented in Table 5 below.

\subsection{Group E: Community, Afterschool or Extracurricular Interventions That Trained Cross-Age Peers}

Four interventions trained cross-age peers to implement interventions outside a classroom setting. All interventions trained high school students, though one intervention also trained undergraduate college students in their first wave [41-44]. Similar to classroombased interventions using cross-age peers, facilitators taught as groups of leaders rather than as individuals. One intervention paired cross-age peers with adults with the goal of training them throughout the intervention to facilitate sessions on their own [40]. Another gave cross-age peers autonomy in scheduling intervention events with younger peers, with adult support available for planning and guidance [65]. Both of these interventions had less consistency in participation among cross-age peers than the one that had a more structured intervention delivery plan [41-44]. The fourth intervention in this group used cross-age peers to develop intervention content that was then used in a virtual format and accompanied lessons taught by adults $[52,53]$. This element of the intervention was noteworthy because it encouraged cross-age peers to tap into their interests, whether sports, ballet, art, etc., and connect that to nutrition content.

One of the interventions conducted post-intervention focus groups with both youth participants and cross-age peers [41-44]. Youth reported they particularly enjoyed the games and cooking lessons. Cross-age peers reported that discussions were the most difficult intervention element in which to engage youth. They noted that it would have been helpful to have more role-playing opportunities during the training to address various scenarios. The leaders also emphasized the importance of communicating simple nutrition messages and having cross-age peers that are representative of the community where they are working. Table 6 describes the interventions included in Group E. 
Table 5. Group D: Community, afterschool, or extracurricular interventions that trained adults.

\begin{tabular}{|c|c|c|c|c|c|c|}
\hline $\begin{array}{l}\text { Author, } \\
\text { Year }\end{array}$ & $\begin{array}{l}\text { Intervention Name } \\
\text { or Description }\end{array}$ & $\begin{array}{l}\text { Population } \\
\text { Characteristics: } \\
\text { Grade Level/Age } \\
\text { (Sample Size), } \\
\text { Location }\end{array}$ & Group Receiving Training & Training Design & $\begin{array}{l}\text { Intervention Frequency } \\
\text { and Duration }\end{array}$ & $\begin{array}{l}\text { Evaluation Indicators and } \\
\text { Notable Results }\end{array}$ \\
\hline $\begin{array}{l}\text { Dubuy, } \\
2014^{1}[33]\end{array}$ & Health Scores! & $\begin{array}{l}\text { 10-14 years old } \\
(n=605), \\
\text { Flanders, Belgium }\end{array}$ & $\begin{array}{l}\text { Professional football players } \\
\text { hosted a start clinic and end } \\
\text { clinic prior to and at the } \\
\text { conclusion of the } \\
\text { classroom-based portion of } \\
\text { the intervention (see } \\
\text { Group A) }\end{array}$ & $\begin{array}{l}\text { While the professional athletes did not } \\
\text { receive formal training from the research } \\
\text { staff, the football clubs were responsible for } \\
\text { organizing the start and end clinics, and } \\
\text { athlete promotion of healthy behaviors was } \\
\text { a key part of the intervention. } \\
\text { At the clinics, the professional athletes } \\
\text { participated in activities with the youth that } \\
\text { encouraged a healthy diet and physical } \\
\text { activity and handed out lifestyle contracts } \\
\text { that youth signed. } \\
\text { Athletes also filmed two video messages } \\
\text { that were shown to the youth at school and } \\
\text { sent two letters reminding students of the } \\
\text { importance of eating healthy and being } \\
\text { active. }\end{array}$ & $\begin{array}{l}4 \text { month in-school } \\
\text { curriculum bookended by } \\
\text { the start and end clinics } \\
\text { with a professional } \\
\text { football team }\end{array}$ & $\begin{array}{l}\text { Outcome: changes in dietary habits, } \\
\text { frequency of breakfast consumption, } \\
\text { eating attitudes and self-efficacy, and } \\
\text { physical activity levels. } \\
\text { Process: youth satisfaction with } \\
\text { professional athlete clinics, response to } \\
\text { videos and letters and overall } \\
\text { satisfaction with the program } \\
\text { See Table } 1 \text { for results }\end{array}$ \\
\hline $\begin{array}{l}\text { Irwin, } \\
2012^{1}[46] \\
+1 \text { paper [47] }\end{array}$ & $\begin{array}{l}\text { Get Fit with the } \\
\text { Grizzlies }\end{array}$ & $\begin{array}{l}\text { 4th and 5th grade } \\
(n=888), \\
\text { Memphis, TN }\end{array}$ & $\begin{array}{l}\text { Memphis Grizzlies players } \\
\text { and staff }\end{array}$ & $\begin{array}{l}\text { While athletes did not receive formal } \\
\text { training, they participated as role models in } \\
\text { the intervention by making visits to } \\
\text { assemblies in participating schools and } \\
\text { hosting an achievement day for youth who } \\
\text { completed the program. }\end{array}$ & $\begin{array}{l}\text { 6-week mini-unit } \\
\text { incorporated into PE } \\
\text { curriculum; one lesson } \\
\text { taught per week. Players, } \\
\text { dancers and/or the mascot } \\
\text { for the Memphis Grizzlies } \\
\text { visited the schools for an } \\
\text { assembly, and there was a } \\
\text { district-wide Get Fit with } \\
\text { the Grizzlies Achievement } \\
\text { Day at Grizzlies home arena } \\
\text { at the end of the program. }\end{array}$ & $\begin{array}{l}\text { Outcome: changes in knowledge, } \\
\text { eating behaviors, and physical } \\
\text { activity habits. } \\
\text { See Table } 1 \text { for results }\end{array}$ \\
\hline
\end{tabular}


Table 5. Cont.

$\begin{array}{ll}\text { Author, } & \begin{array}{l}\text { Intervention Name } \\ \text { or Description }\end{array}\end{array}$

Population

Characteristics:

Grade Level/Ag

(Sample Size),

Group Receiving Training

Training Design

Intervention Frequency

Location
Kohlstatdt

$2016^{2}$ [52]

+1 paper [53]
NutriBee

\section{4th-7th grad}

$(n=179)$,

New Mexico,

Michigan,

Maryland and

Guam professionals. Intervention was conducted in

afterschool or weekend

clubs, or in camp settings
Received $1-3 \mathrm{~h}$ of experiential in-person instruction designed to parallel the form of the intervention itself, including a culminating game show. Also received an instructor training manual and

informational video.

After completion of the intervention,

instructors received a stipend and certificate and Duration across varying time frame ranging from 4 days (in camp settings) to 1 month (club that met once/week)

\section{aluation Indicators and}

\section{Notable Results}

Outcome: changes in dietary

knowledge, intentions, outcom expectations, self-efficacy, and dietary intake.

Results:

Selection of dried and fresh fruit and

bottled water increased, and

consumption of sugary sports

drinks decreased.

Process: measured dose, fidelity,

and acceptability.

Results:

Acceptability was based on

appropriateness of difficulty and

appropriateness of length. Scores

ranged from 1.5 to 1.8 out of a

maximum of 2 .

Outcome: changes in attitude,

perception of control, self-efficacy,
Groups are run

independently, and length

varies by project; average

was 9 sessions over a

9-22 years was

all groups:

Adult mentors/ Training is a half-day session that covers

leaders of youth groups in a gathering necessary resources for the

variety of settings

6 middle school $\quad$ (after-school programs,

6 high school,

and Action for

8 community cente

community organizations, eating and/or active living, identifying

religious organizations)

Health (YEAH!)

who are interested in
10 -week period. With

Linton, Youth Engagement

church

youth group

$(n=136)$,

activity-

related community

advocacy projects. community decision makers, and advocacy. Adult leaders receive the YEAH! manual as part of the training and have access to ongoing technical support from the Sand Diego County Childhood Obesity Initiative throughout their projects. guidance from an adult

mentor, youth groups assess

their food and built

environment, prioritize

problems identified in the

assessment, and develop

and implement an action

plan to advocate with

decision makers for change

in their community. readiness to act as social change advocates and health behavior.

Process: retention of youth throughout

project, number of meetings with

decision makers.

Results:

$73 \%$ of youth participants across all groups remained engaged throughout their group's project.

19 of 20 groups in the evaluation had in-person meetings or presentations with decision makers. 11 groups

reported changes in the community as a result of their work, and 4 reported pending changes. 
Table 5. Cont.

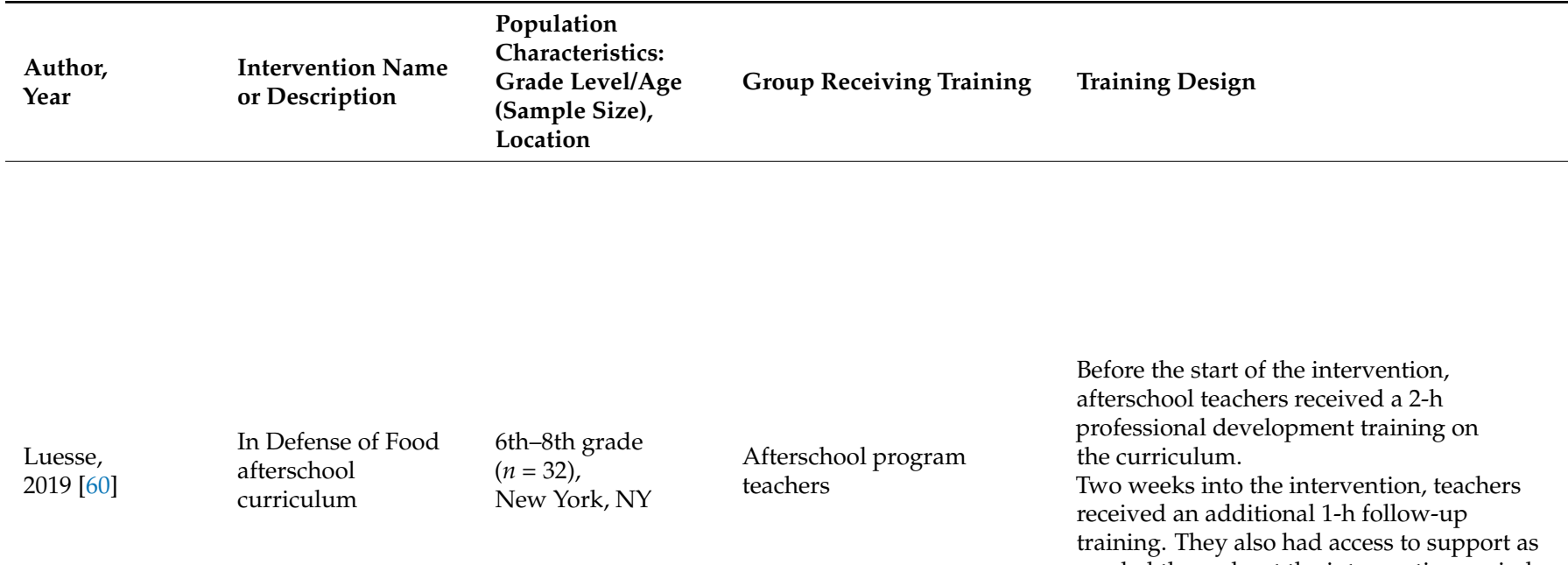

Intervention Frequency

and Duration

\section{Evaluation Indicators and Notable}

Results

Outcome: changes in dietary intake, outcome expectations, self-efficacy, self-regulation skills and autonomous motivation. Results:

There was a significant increase in fruit and vegetable intake post-

10 weeks, one 2-h afterschool session each week. The curriculum is divided into 3 units of 3 lessons each and a final training. They also had access to support as culminating lesson. intervention.

Qualitative: assessment of student understanding and ability to apply "food rules" from each lesson and semi-structured interviews with youth to better understand target outcomes. Results:

Youth best understood "rules" related to drinking water and moderation. In interviews, youth noted that the social and physical environment made it difficult to decrease consumption of processed foods even when they desired to do so.

\section{Qualitative: focus group transcripts} were coded, and themes were identified. Results:

Qualitative study

that examined

factors that mediate

fruit and vegetable

Molaison, consumption among southern, $(n=42)$ 2 counties in the low-income black adolescents to aid in planning an

planning an of Mississippi
Focus groups were conducted with youth National Youth Sports Graduate students and

research staff who were of 3-day workshop provided training in the same ethnic or racial ower Delta region background as the youth National Youth Sports Program. Groups were (10-11, 12, and 13 , for 6 age: $10-11,12$, and 13 , for 6 groups total. Each focus group met once during the 5-week summer program session.
Taste and method of preparation were major factors limiting fruit and vegetable consumption, especially for vegetables.

Additional limiting factors were lack of availability of fruits and vegetables at home or in neighborhood stores and limited control over their food option. limiter coptions. Most had family support for fruit a vegetable consumption, but not peer support. 
Table 5. Cont.

\begin{tabular}{|c|c|c|}
\hline $\begin{array}{l}\text { Author, } \\
\text { Year }\end{array}$ & $\begin{array}{l}\text { Intervention Name } \\
\text { or Description }\end{array}$ & $\begin{array}{l}\text { Population } \\
\text { Characteristics: } \\
\text { Grade Level/Age } \\
\text { (Sample Size), } \\
\text { Location }\end{array}$ \\
\hline $\begin{array}{l}\text { Tucker, } \\
2015^{1}[70]\end{array}$ & $\begin{array}{l}\text { Let's Go } 5-2-1-0 \\
\text { childhood obesity } \\
\text { prevention } \\
\text { intervention } \\
\text { delivered by school } \\
\text { nurses plus } 1: 1 \text { or } \\
\text { small group } \\
\text { coaching by nursing } \\
\text { students }\end{array}$ & $\begin{array}{l}4 \text { th and 5th grade } \\
(n=72) \text {, } \\
\text { Location not } \\
\text { specified; } \\
\text { corresponding } \\
\text { author affiliated } \\
\text { with University of } \\
\text { Iowa }\end{array}$ \\
\hline
\end{tabular}

\section{Group Receiving Training Training Desig}

Training was provided in the 5-2-1-0

curriculum, basic motivational interviewing

(MI) principles for behavior change, and

role modeling healthy behavior.

Training included a didactic portion, role

playing, and use of videos.

Intervention also included

classroom component with

school nurses (see Group A)

At one nursing school, training consisted of

an initial 4-h session followed by weekly

sessions of practice and role plays.

At the other nursing school, a 2-h training

session was provided.

Training took place in a full-day, in-person

An advanced practice nurse, registered nurses, a physical education specialist, and

Wright,

Kids Nutrition and

$8-12$ years old

2012 [71]

Fitness community health workers$$
\text { volunteers) }
$$

session that covered all intervention

information and examples for the nutrition education component.

Retraining was provided on an as-needed basis if instructors were not following the intervention protocol during session observations.
Intervention Frequency and Duration

\section{Evaluation Indicators and Notable}

Results

The intervention ran from September to April in one school and January to April in the other school. School nurses delivered the Let's

Go 5-2-1-0 curriculum

weekly during classroom

instructional time in

10-15 increments. Dosage

varied from 14-21 sessions.

Nursing students had lunch
with their assigned

student/students once a

week to discuss curriculum

content and set goals for

intervention topics.

6-week afterschool program with weekly 90-min sessions. Students were

recruited and went through the program in waves of

14-28 at a time.

Beyond the curriculum, the intervention also included school and

community-level activities,

including physical and

mental health service

through local clinics.
Outcome: changes in anthropometrics,

Outcome: changes in anthropometric measurements, physical activity levels, nutrition, family eating patterns, and

screen time.

See Table 1 for result dietary behaviors, food preferences,

knowledge, and self-efficacy Results:

Self-reported intake of fruit, vegetables and $100 \%$ fruit juice increased

significantly at post-intervention and was sustained at 12-month follow-up. Process: intervention fidelity assessed by session observations, focus groups with parents. 
Table 5. Cont.

\begin{tabular}{|c|c|c|c|c|c|c|}
\hline $\begin{array}{l}\text { Author, } \\
\text { Year }\end{array}$ & $\begin{array}{l}\text { Intervention Name } \\
\text { or Description }\end{array}$ & $\begin{array}{l}\text { Population } \\
\text { Characteristics: } \\
\text { Grade Level/Age } \\
\text { (Sample Size), } \\
\text { Location }\end{array}$ & Group Receiving Training & Training Design & $\begin{array}{l}\text { Intervention Frequency } \\
\text { and Duration }\end{array}$ & $\begin{array}{l}\text { Evaluation Indicators and Notable } \\
\text { Results }\end{array}$ \\
\hline
\end{tabular}

${ }^{1}$ Also included in Group A. ${ }^{2}$ Also included in Group E. 
Table 6. Group E: Community, afterschool, or extracurricular interventions that trained cross-age peers.

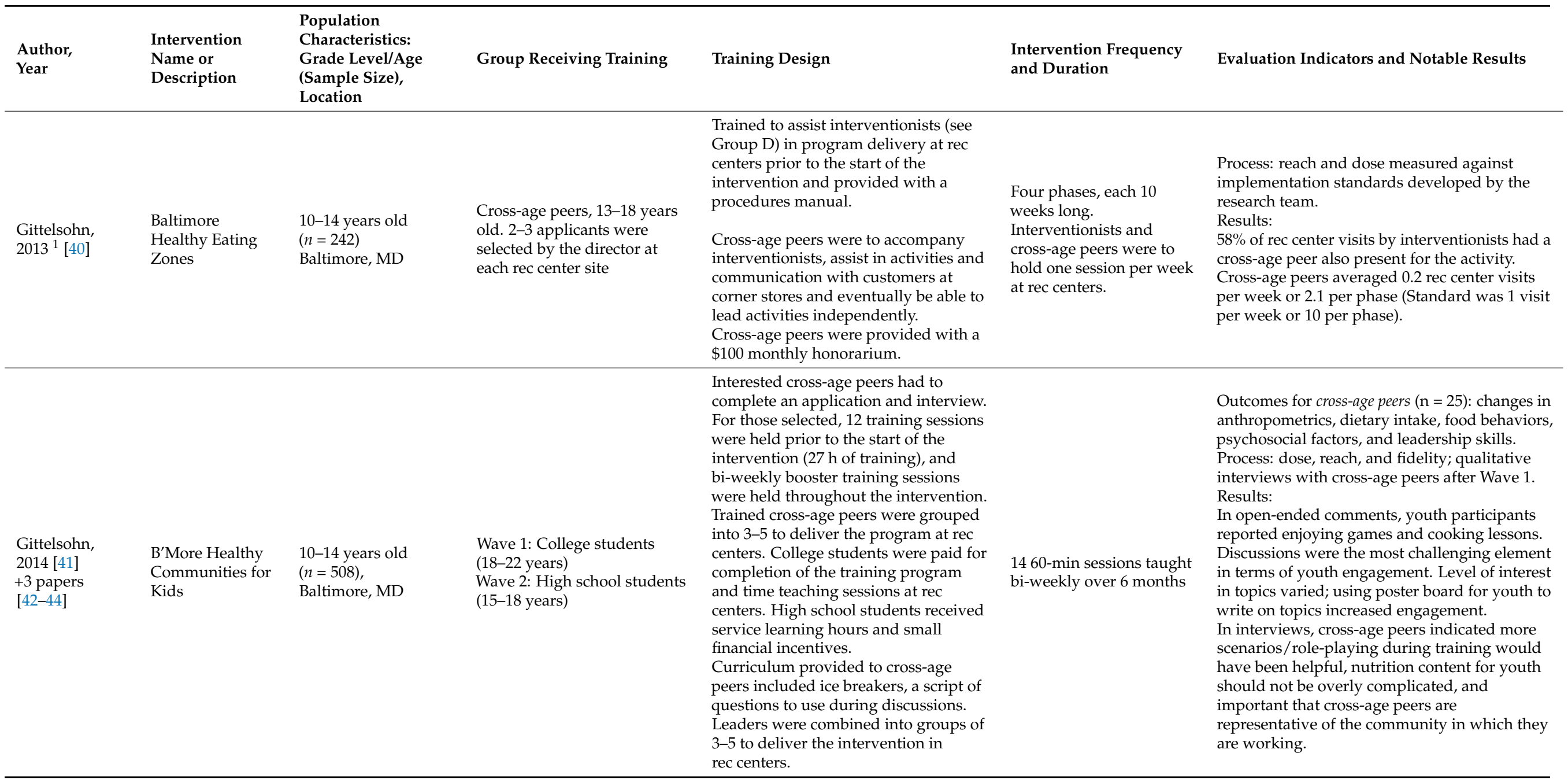


Table 6. Cont.

\begin{tabular}{|c|c|c|c|c|c|c|}
\hline $\begin{array}{l}\text { Author, } \\
\text { Year }\end{array}$ & $\begin{array}{l}\text { Intervention } \\
\text { Name or } \\
\text { Description }\end{array}$ & $\begin{array}{l}\text { Population } \\
\text { Characteristics: } \\
\text { Grade Level/Age } \\
\text { (Sample Size), } \\
\text { Location }\end{array}$ & Group Receiving Training & Training Design & $\begin{array}{l}\text { Intervention Frequency } \\
\text { and Duration }\end{array}$ & Evaluation Indicators and Notable Results \\
\hline $\begin{array}{l}\text { Saez, } \\
2018^{2}[65]\end{array}$ & $\begin{array}{l}\text { Peer intervention } \\
\text { was carried out } \\
\text { within the larger } \\
\text { PRALIMAP- } \\
\text { INĖS (Promotion } \\
\text { de l'ALIMentation } \\
\text { et l'Activité } \\
\text { Physique- } \\
\text { INEgalité } \\
\text { de Santé) }\end{array}$ & $\begin{array}{l}\text { Grade } 9 \text { (last year of } \\
\text { middle school) and } \\
\text { Grade } 10 \text { (first year of } \\
\text { high school) } \\
(n=32) \text {, } \\
\text { Vosges, France }\end{array}$ & $\begin{array}{l}\text { Cross-age peers (peer } \\
\text { ambassadors) had } \\
\text { participated in the program } \\
\text { the previous year and were } \\
\text { one year ahead of the target } \\
\text { population in school } \\
\text { (Intervention also used } \\
\text { same-age peers; see Group F) } \\
\text { To be eligible, peers had to } \\
\text { have a demonstrated ability to } \\
\text { control their weight and be of } \\
\text { a similar socioeconomic } \\
\text { background as the } \\
\text { target population. }\end{array}$ & $\begin{array}{l}\text { Peers received a 2-h training session at } \\
\text { the start of the school year, in groups of } \\
2-4 \text { at a time or individually if } \\
\text { grouping was not possible. } \\
\text { During the training, cross-age peers } \\
\text { considered the strengths they would } \\
\text { bring as intervention facilitators. They } \\
\text { then brainstormed activities they could } \\
\text { lead and practiced role-playing various } \\
\text { scenarios they might encounter. } \\
\text { Following role-playing, they received } \\
\text { feedback and debriefing tips. } \\
\text { Cross-age peers discussed their } \\
\text { planned activities with the program } \\
\text { coordinator; financial support was } \\
\text { available if needed for the activities. } \\
\text { They had regular contact with the } \\
\text { program coordinator throughout the } \\
\text { school year via phone and text } \\
\text { messages for follow-up and support } \\
\text { and had a mid-year } \\
\text { face-to-face meeting. }\end{array}$ & $\begin{array}{l}\text { Target was for cross-age } \\
\text { peers to plan and carry } \\
\text { out four activities with } \\
\text { their assigned small } \\
\text { group of younger peers } \\
\text { throughout the school } \\
\text { year. } \\
\text { The peer intervention was } \\
\text { part of a larger health } \\
\text { intervention in the school } \\
\text { setting and was meant to } \\
\text { be more informal in its } \\
\text { approach, where activities } \\
\text { could also be conducted } \\
\text { outside of school. }\end{array}$ & $\begin{array}{l}\text { Outcome: changes in physical activity, mental } \\
\text { health, and perceived health and quality of life } \\
\text { Process: satisfaction, perceived appropriateness, } \\
\text { dose received, and practicality } \\
\text { Results: } \\
\text { A total of } 5 \text { cross-age peers were trained and } \\
\text { remained active out of } 20 \text { potential facilitators } \\
\text { who initially accepted the invitation, and } 1 \\
\text { successfully organized and implemented an } \\
\text { activity. } \\
\text { Youth were significantly more likely to accept } \\
\text { the peer intervention when offered by the peer } \\
\text { rather than an adult professional. Interestingly, } \\
\text { though some youth reported mistrust of peers } \\
\text { and concerns about social exclusion. } \\
\text { Facilitators had a high need for support from } \\
\text { the program coordinator and despite } \\
\text { addressing this topic in the training, struggled } \\
\text { to come of up with ideas for activities. } \\
\text { Training feedback indicated that more than } 2 \mathrm{~h} \\
\text { was needed, and more practical ideas for } \\
\text { activities and interpersonal skills training } \\
\text { would be helpful. }\end{array}$ \\
\hline
\end{tabular}

${ }^{1}$ Also included in Group D. ${ }^{2}$ Also included in Group F. 
3.6. Group F: Community, Afterschool or Extracurricular Interventions That Trained Same-Age Peers

Ten interventions in our review trained same-age peers to deliver nutrition education information outside a classroom context. These interventions were generally less structured than those that were classroom-based; only one had a weekly schedule of lessons that peers delivered [68]. A key theme across this group of interventions was having simple messaging that was easy for same-age peers to use in conversation, whether in an informal or more formal context.

Three interventions were informal in their structure: same-age peers were trained and then tasked with spreading the messages through their normal social networks $[23,39,66]$. Two of these were essentially the same intervention implemented in two different countries and focused on promoting water consumption $[39,66]$. Peers brought up water consumption in conversation and also modeled drinking water throughout the day. Of note, these interventions measured changes in SSB intake as well as in water intake, but the message was positively focused on water consumption rather than on decreasing SSB consumption.

Four of the interventions took place either during the school lunch period or after school. Same-age peers promoted healthy eating and conducted taste tests in the cafeteria [24-26], planned their own events with peers [65], or taught lessons and promoted nutrition messages through club activities [68]. The remaining three interventions involved a small group of the target population who participated in afterschool programs where nutrition was incorporated into another activity. Two of these interventions were photovoice projects, where youth took pictures in their neighborhoods that gave visual representation to the food environment and then showcased their work in a community exhibition [55,63]. In one of the photovoice projects, a student took her photographs of the school cafeteria food to the food service director and successfully advocated for healthier options [63]. The third of these types of interventions was an afterschool theater program in which youth wrote a play about healthy eating and performed it in a dinner theater setting for their friends and family [48]. These interventions represent creative ways for youth to connect nutrition with other hobbies or interests and to use their voices to advocate for the health of their community. The interventions in Group F are further described in Table 7. 
Table 7. Group F: Community, afterschool or extracurricular interventions that trained same-age peers.

Author, Intervention Name or Description
Population

Grade Level/Age

Grade Level/Age
(Sample Size),

Location
Group Receiving Training

Training Design

and Duration
Evaluation Indicators and

Notable Results

\begin{tabular}{|c|c|c|c|c|c|c|}
\hline $\begin{array}{l}\text { Bell, } \\
2017 \text { [23] }\end{array}$ & $\begin{array}{l}\text { Activity and Healthy Eating } \\
\text { in ADolescence (AHEAD) }\end{array}$ & $\begin{array}{l}\text { Year } 8 \\
\text { (equivalent to } \\
\text { U.S. 7th grade) } \\
\text { ( } n=99 \text { in pilot, } \\
n=928 \text { in } \\
\text { exploratory trial), } \\
\text { Bristol, UK }\end{array}$ & $\begin{array}{l}\text { Peers leaders from within the } \\
\text { target population. In the pilot, } \\
19 \% \text { were trained as peer } \\
\text { supporters and in the } \\
\text { exploratory trial, } 17 \% \\
\text { were trained. } \\
\text { All Year } 8 \text { students filled out a } \\
\text { nomination questionnaire and } \\
\text { those with the most } \\
\text { nominations were invited to a } \\
\text { peer leader } \\
\text { recruitment meeting. }\end{array}$ & $\begin{array}{l}\text { Initial training for peer leaders was a } \\
\text { two-day out-of-school event. Sessions } \\
\text { used drama, food preparation, } \\
\text { technology and games to deliver key } \\
\text { nutrition and physical activity } \\
\text { messages to peer leaders. Content } \\
\text { supported school curriculum and } \\
\text { national school health programs. Each } \\
\text { peer leader received a diary to write } \\
\text { about interactions with their peers; } \\
\text { diaries included healthy challenges to } \\
\text { encourage behavior change. } \\
\text { Peer leaders walked to the training to } \\
\text { promote active transport, and food and } \\
\text { drinks served at the training were } \\
\text { prepared on site, with the help of peer } \\
\text { leaders when possible. } \\
\text { Trainers included master's degree } \\
\text { students and professional health and } \\
\text { well-being trainers. } \\
\text { Four school-based follow-up sessions } \\
\text { were held with peer leaders throughout } \\
\text { the school year. }\end{array}$ & $\begin{array}{l}\text { Peer leaders were tasked } \\
\text { with informally diffusing } \\
\text { the health messages they } \\
\text { learned in the training and } \\
\text { modeling healthy behavior } \\
\text { over the course of the school } \\
\text { year. Post-intervention } \\
\text { behavioral questionnaires } \\
\text { were used to assess the } \\
\text { extent of the diffusion, and } \\
\text { focus groups were } \\
\text { conducted with non-peer } \\
\text { leader intervention } \\
\text { participants. }\end{array}$ & $\begin{array}{l}\text { Outcome: changes in diet and } \\
\text { physical activity behaviors. } \\
\text { Results: } \\
\text { Post-intervention, students ate } \\
\text { significantly more servings of } \\
\text { fruit a day and ate breakfast } \\
\text { significantly more often than } \\
\text { students from a comparable } \\
\text { control group. } \\
\text { Process: recruitment and } \\
\text { retention rates for peer leaders, } \\
\text { structured observation and } \\
\text { evaluation of training sessions, } \\
\text { post- } \\
\text { intervention focus groups with } \\
\text { both peer leaders and non-peer } \\
\text { leader intervention participants. } \\
\text { Results: } \\
\text { Peer leaders responded } \\
\text { especially well to hands-on } \\
\text { activities, games and } \\
\text { role-playing in the trainings. } \\
\text { School-based trainings were less } \\
\text { enjoyable to students than the } \\
\text { initial trainings held offsite. } \\
\text { About } 1 / 3 \text { of intervention } \\
\text { participants were aware of } \\
\text { having talked with a peer leader } \\
\text { about healthy messages and } \\
\text { reported that this encouraged } \\
\text { them to increase healthy } \\
\text { behaviors. }\end{array}$ \\
\hline
\end{tabular}


Table 7. Cont.

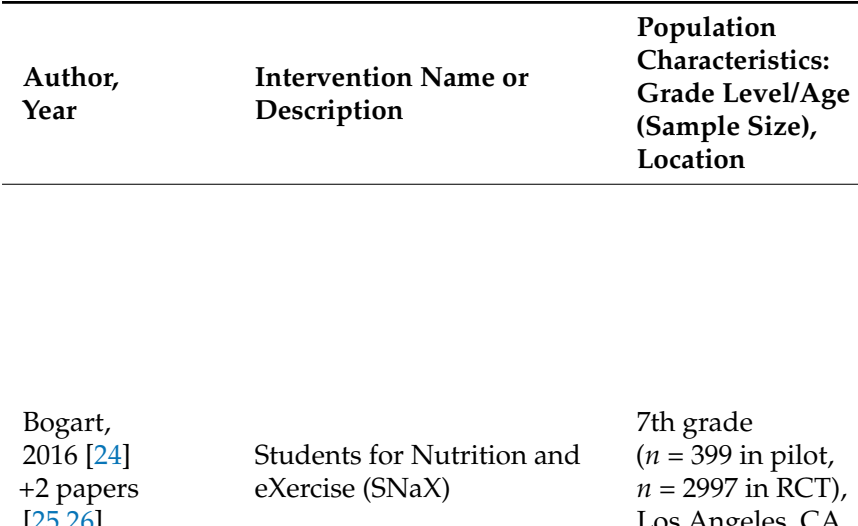

\section{Group Receiving Training}

\section{Training Design}

Peer leaders attended a training session where they were taught to discus $\mathrm{SNaX}$ messages with peers and family using motivational interviewing (MI)

Peer leaders from within the target population. $21 \%$ of 7 th graders were trailed during the pilot and $23 \%$ were trained during the RCT. A different group of leaders was recruited each week and each leader was asked to also recruit a part

techniques. During the training, they

engaged in role-playing using MI. They then recruited a friend to co-facilitate two lunchtime educational sessions with them.

Peer leader training sessions were conducted by bachelor's level facilitators who were themselve trained by a Ph.D. level clinical

psychologist (4 $\mathrm{h}$ on motivational interviewing) and a Ph.D. level public

health researcher $(20 \mathrm{~h}$ on

intervention content)

Training was $90 \mathrm{~min}$ and held during school hours. Peer leaders learned about the benefits of wat

Peer leaders from within the target population. The $15 \%$ of boys and $15 \%$ of girls with the most nominations from the attend the training to become peer leaders.
5 th and 6th grade

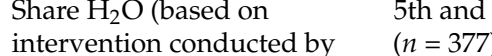
Smit, 2016) $(n=377)$ consumption, worked on formulating their own arguments for increasing water consumption, practiced strategies for promoting water consumption with their peers and were encouraged to set an example with their own water consumption.

Peer leaders received follow-up

training sessions in weeks two and five of the intervention.

\section{Intervention Frequency}

and Duration

\section{Evaluation Indicators and}

Notable Results

5 weeks with two lunchtime sessions per week facilitated by peer leaders that could include taste tests and giving out of promotional items. Intervention also included school food environment changes and school-wide marketing of

$\mathrm{SNaX}$ messages.

Peer leaders were tasked with promoting water consumption to their peers through their social networks over a period of 8 weeks.
Outcome: changes in school lunch participation and cafeteria purchases, BMI classification change over time, attitudes about the cafeteria and water

consumption, intentions to drink water, and water consumption. Results:

Fruit servings significantly increased in intervention schools, and students also drank tap water significantly more often post-intervention compared with control schools.

Process: researchers monitored peer leader training sessions for coverage of all session elements.

Outcome: changes in

consumption of water and SSBs and behavioral intention around beverage consumption. Student were also asked how often their were also asked how often their friends consumed water and how disapproved of them consuming water.

Results:

Students in the intervention group consumed significantly less SSBs post-intervention compared with control group. Those with a high perception of their friends' approval for drinking water consumed significantly more water. 
Table 7. Cont.

\begin{tabular}{|c|c|c|c|c|c|c|}
\hline $\begin{array}{l}\text { Author, } \\
\text { Year }\end{array}$ & $\begin{array}{l}\text { Intervention Name or } \\
\text { Description }\end{array}$ & $\begin{array}{l}\text { Population } \\
\text { Characteristics: } \\
\text { Grade Level/Age } \\
\text { (Sample Size), } \\
\text { Location }\end{array}$ & Group Receiving Training & Training Design & $\begin{array}{l}\text { Intervention Frequency } \\
\text { and Duration }\end{array}$ & $\begin{array}{l}\text { Evaluation Indicators and } \\
\text { Notable Results }\end{array}$ \\
\hline $\begin{array}{l}\text { Heo, } \\
2018^{1}[45]\end{array}$ & HealthCorps & $\begin{array}{l}\text { High school } \\
(n=832), \\
\text { New York, NY }\end{array}$ & $\begin{array}{l}\text { Students from among the } \\
\text { target population could elect } \\
\text { to join the Youth Lead Action } \\
\text { Research program or } \\
\text { participate in facilitating } \\
\text { lunchroom activities. }\end{array}$ & $\begin{array}{l}\text { Paper does not include description of } \\
\text { formalized training for same-age peers; } \\
\text { leadership in healthy eating comes } \\
\text { through participation in the program } \\
\text { activities beyond the classroom. } \\
\text { In Youth Lead Action Research, } \\
\text { students learn research methods to } \\
\text { identify health needs in their school or } \\
\text { community and develop projects that } \\
\text { address those needs. } \\
\text { In the lunchroom, youth work } \\
\text { alongside the program coordinator (see } \\
\text { Group A) to share samples of healthy } \\
\text { foods and engage with their peers on a } \\
\text { monthly basis. }\end{array}$ & $\begin{array}{l}10 \text { classroom lessons are } \\
\text { delivered as part of the } \\
\text { curriculum. Were delivered } \\
\text { over the course of a } \\
\text { semester or school year, } \\
\text { depending on the school. } \\
\text { For students participating } \\
\text { in program activities } \\
\text { outside the classroom, total } \\
\text { exposure could be up to } \\
45 \mathrm{~h} \text { over a maximum } \\
36 \text { weeks. }\end{array}$ & $\begin{array}{l}\text { Outcome: changes in } \\
\text { anthropometrics, knowledge, } \\
\text { and health behavior. } \\
\text { Results: } \\
\text { Students participating in } \\
\text { HealthCorps significantly } \\
\text { increased fruit and vegetable } \\
\text { intake post-intervention; there } \\
\text { was no change in fruit and } \\
\text { vegetable consumption from pre } \\
\text { to post-intervention in the } \\
\text { comparison group. } \\
\text { Process: site visit by program } \\
\text { supervisor to ensure fidelity in } \\
\text { curriculum delivery. }\end{array}$ \\
\hline $\begin{array}{l}\text { Jackson, } \\
2010[48]\end{array}$ & Healthy 4 Life & $\begin{array}{l}\text { 6th-8th grade } \\
(n=15) \\
\text { Urban area, } \\
\text { southeastern GA }\end{array}$ & $\begin{array}{l}\text { Intervention participants } \\
\text { themselves developed a } \\
\text { theater production that } \\
\text { communicated nutrition and } \\
\text { physical activity to friends } \\
\text { and family. }\end{array}$ & $\begin{array}{l}\text { Each session began with nutrition and } \\
\text { physical activity topics, team-building } \\
\text { activities introduced theater dynamics, } \\
\text { students made a healthy recipe or } \\
\text { snack after the theater activity and } \\
\text { ended with a physical activity session. }\end{array}$ & $\begin{array}{l}6 \text { weeks, } 75 \text {-min afterschool } \\
\text { sessions twice per week. } \\
\text { Throughout the six weeks, } \\
\text { students used what they } \\
\text { learned about nutrition, } \\
\text { physical activity, and } \\
\text { theater to develop a play, } \\
\text { Getting on Track, which } \\
\text { they gave as a dinner } \\
\text { theater performance for } \\
\text { family and friends. }\end{array}$ & $\begin{array}{l}\text { Changes in knowledge, food and } \\
\text { physical activity choices, and } \\
\text { behavioral norms. } \\
\text { Results: } \\
\text { Small sample size gave } \\
\text { insufficient power to generate } \\
\text { statistical significance, but more } \\
\text { students reported choosing fruit } \\
\text { over sweets post- } \\
\text { intervention. }\end{array}$ \\
\hline
\end{tabular}


Table 7. Cont.

\begin{tabular}{|c|c|c|c|c|c|c|}
\hline $\begin{array}{l}\text { Author, } \\
\text { Year }\end{array}$ & $\begin{array}{l}\text { Intervention Name or } \\
\text { Description }\end{array}$ & $\begin{array}{l}\text { Population } \\
\text { Characteristics: } \\
\text { Grade Level/Age } \\
\text { (Sample Size), } \\
\text { Location }\end{array}$ & Group Receiving Training & Training Design & $\begin{array}{l}\text { Intervention Frequency } \\
\text { and Duration }\end{array}$ & $\begin{array}{l}\text { Evaluation Indicators and } \\
\text { Notable Results }\end{array}$ \\
\hline $\begin{array}{l}\text { Leung, } \\
2017[55]\end{array}$ & $\begin{array}{l}\text { Intervention incorporated } \\
\text { photovoice into a food } \\
\text { justice curriculum for } \\
\text { middle school youth. }\end{array}$ & $\begin{array}{l}\text { 6th-8th grade } \\
(n=12) \\
\text { East Harlem, NY }\end{array}$ & $\begin{array}{l}\text { Intervention participants } \\
\text { themselves used photovoice } \\
\text { to conduct a community food } \\
\text { assessment and conduct a } \\
\text { food justice project, then } \\
\text { presented their photos and } \\
\text { projects to the community. }\end{array}$ & $\begin{array}{l}\text { Sessions covered photography and } \\
\text { photovoice; the food system and } \\
\text { environmental influences on food } \\
\text { choices; a community food assessment } \\
\text { photographing barriers and facilitators } \\
\text { of eating healthy in the neighborhood; } \\
\text { discussions of potential solutions to } \\
\text { community food issues and roles youth } \\
\text { could play in promoting change; and } \\
\text { interviews of community members to } \\
\text { understand their experience of the food } \\
\text { environment. } \\
\text { Throughout the intervention, } \\
\text { facilitators reinforced the role of youth } \\
\text { as researchers and active participants in } \\
\text { changing their community. }\end{array}$ & $\begin{array}{l}24 \text { weeks total. The first } 10 \\
\text { weeks focused on } \\
\text { photovoice and included } 6 \\
90 \text {-min sessions at an } \\
\text { afterschool program and } 3 \\
\text { photo assignments. In the } \\
\text { second } 14 \text { weeks, youth } \\
\text { developed and } \\
\text { implemented a food justice } \\
\text { project. A celebration and } \\
\text { photo exhibit were held at } \\
\text { the end of the } 24 \text { weeks } \\
\text { where youth shared and } \\
\text { discussed their photos and } \\
\text { project with } \\
\text { community members. }\end{array}$ & $\begin{array}{l}\text { Qualitative interviews and } \\
\text { subsequent analysis to } \\
\text { identify themes. } \\
\text { Results: } \\
\text { Through photos and focus } \\
\text { groups, participants: (1) } \\
\text { expressed distrust of the food } \\
\text { industry, (2) identified the } \\
\text { abundance of low-cost, } \\
\text { unhealthy foods and product } \\
\text { placement as barriers to healthy } \\
\text { choices, (3) noted the importance } \\
\text { family influence on their food } \\
\text { choices and also their potential to } \\
\text { be change agents in their family, } \\
\text { (4) expressed concern about the } \\
\text { health of family members and } \\
\text { their own health, and (5) } \\
\text { identified strategies for } \\
\text { improving the food environment. }\end{array}$ \\
\hline $\begin{array}{l}\text { Necheles, } \\
2007 \text { [63] }\end{array}$ & The Teen Photovoice Project & $\begin{array}{l}\text { 13-17 years old } \\
(n=13), \\
\text { Los Angeles, CA }\end{array}$ & $\begin{array}{l}\text { Intervention participants, all } \\
\text { of whom were members of the } \\
\text { Youth Advisory Board from } \\
\text { the UCLA/RAND Center for } \\
\text { Adolescent Health Promotion } \\
\text { (the center), used photovoice } \\
\text { and resulting themes to create } \\
\text { health education messages } \\
\text { that were then presented to } \\
\text { the community. }\end{array}$ & $\begin{array}{l}\text { Sessions covered photography and } \\
\text { photovoice, qualitative research } \\
\text { methods, sorting and selecting photos, } \\
\text { creating narrative on photos, } \\
\text { generating themes, generating ideas for } \\
\text { health education products, planning for } \\
\text { opening exhibit. }\end{array}$ & $\begin{array}{l}\text { Over a period of five } \\
\text { months, youth participated } \\
\text { in } 92 \text {-h afterschool sessions. } \\
\text { In small groups, they } \\
\text { selected a concept for a } \\
\text { health education poster, } \\
\text { photos to use on the poster } \\
\text { and the text for } \\
\text { communicating the health } \\
\text { message. An opening } \\
\text { exhibit for the posters was } \\
\text { held at the California } \\
\text { Science Center. }\end{array}$ & $\begin{array}{l}\text { Outcomes of the project were the } \\
\text { creation of the posters and the } \\
\text { opening exhibit. } \\
\text { Results: } \\
\text { Following the project, youth } \\
\text { encouraged the center to do more } \\
\text { research on childhood obesity } \\
\text { using youth participatory } \\
\text { research methods. } \\
\text { One student took the initiative to } \\
\text { share photos of unhealthy food } \\
\text { sold in the school cafeteria with } \\
\text { the school foodservice director } \\
\text { and advocated for } \\
\text { healthier options. }\end{array}$ \\
\hline
\end{tabular}


Table 7. Cont.

\begin{tabular}{|c|c|c|c|c|c|c|}
\hline $\begin{array}{l}\text { Author, } \\
\text { Year }\end{array}$ & $\begin{array}{l}\text { Intervention Name or } \\
\text { Description }\end{array}$ & $\begin{array}{l}\text { Population } \\
\text { Characteristics: } \\
\text { Grade Level/Age } \\
\text { (Sample Size), } \\
\text { Location }\end{array}$ & Group Receiving Training & Training Design & $\begin{array}{l}\text { Intervention Frequency } \\
\text { and Duration }\end{array}$ & $\begin{array}{l}\text { Evaluation Indicators and } \\
\text { Notable Results }\end{array}$ \\
\hline
\end{tabular}


Table 7. Cont.

\begin{tabular}{|c|c|c|c|c|c|}
\hline $\begin{array}{l}\text { Author, } \\
\text { Year }\end{array}$ & $\begin{array}{l}\text { Intervention Name or } \\
\text { Description }\end{array}$ & $\begin{array}{l}\text { Population } \\
\text { Characteristics: } \\
\text { Grade Level/Age } \\
\text { (Sample Size), } \\
\text { Location }\end{array}$ & Group Receiving Training & Training Design & $\begin{array}{l}\text { Intervention Frequency } \\
\text { and Duration }\end{array}$ \\
\hline $\begin{array}{l}\text { Smit, } \\
2016[66]\end{array}$ & Share $\mathrm{H}_{2} \mathrm{O}$ & $\begin{array}{l}9-13 \text { years old } \\
(n=210), \\
\text { The Netherlands }\end{array}$ & $\begin{array}{l}\text { Peer leaders from within the } \\
\text { target population. The } 15 \% \text { of } \\
\text { boys and } 15 \% \text { of girls with the } \\
\text { most nominations from their } \\
\text { classmates were invited to } \\
\text { attend the training to become } \\
\text { peer leaders. }\end{array}$ & $\begin{array}{l}\text { Training was } 90 \mathrm{~min} \text { and held during } \\
\text { school hours. Peer leaders learned } \\
\text { about the benefits of water } \\
\text { consumption, worked on formulating } \\
\text { their own arguments for increasing } \\
\text { water consumption, practiced strategies } \\
\text { for promoting water consumption with } \\
\text { their peers, and were encouraged to set } \\
\text { an example with their own water } \\
\text { consumption. Water consumption from } \\
\text { reusable bottles was also connected to } \\
\text { environmental health. } \\
\text { During the training, peer leaders } \\
\text { identified drinking water themselves } \\
\text { and sharing the health and } \\
\text { environmental benefits of water } \\
\text { consumption as key messages. } \\
\text { Follow-up training sessions were } \\
\text { provided during weeks } 2 \text { and } 4 \text { of the } \\
\text { intervention. }\end{array}$ & $\begin{array}{l}\text { Peer leaders were tasked } \\
\text { with promoting water } \\
\text { consumption to their peers } \\
\text { through their social } \\
\text { networks over a period of } \\
8 \text { weeks. }\end{array}$ \\
\hline
\end{tabular}

Peer leaders had a training session with the research team to learn about their role and responsibilities. Leaders were provided with health promotion

education intervention that 11-19 years old included health promotion through school media and clubs, as well as school and

Tamiru, community event $(n=992)$

Peer leaders selected from Jimma, Ethiopia among the target population
Teachers held peer dialogue sessions peer educators.
Outcome: water and SSB

consumption, intention to drink more water

Results:

Students in the intervention group reported a significan increase in water consumption and a significant decrease in SSB consumption post-intervention compared to a control group.

Outcome: changes in knowledge, attitude, dietary quality and measurements. The study also assessed food insecurity and its relationship to dietary intake. Over 8 months, peer leaders Results: taught a group of fellow

Youth from food secure students via demonstration households had significantly and role-playing in higher dietary diversity compared with those from food insecure households. More than 2/3 of students reported their food was selected by their parent/guardian as opposed to self- selected. 


\section{Discussion}

This review synthesizes components of nutrition education interventions targeting middle school-age students across a wide range of settings and program designs, all of which incorporate some version of a train-the-trainer model. The use of a framework synthesis approach to organize the interventions allowed for key themes to emerge from various settings that can inform future nutrition education interventions that employ train-the-trainer methodology and target the middle school population, especially in lowresource, urban settings. By focusing on training components, intervention content and design, and process evaluation results rather than primarily on outcomes $[10,11]$, this review makes a unique contribution to the literature on youth nutrition education interventions.

Our first dimension for synthesis of themes centered on train-the trainer approaches, and we found that engaging sessions that provide opportunities for role play and talking through scenarios that may arise with the target youth were well-received [49-51,56,57,70,72,73], especially when those being trained were cross-age or same-age peers $[24,25,38,65]$. For example, the Foley et al. paper describes trainers interactively teaching the curriculum to cross-age peers and then giving the youth the opportunity to practice teaching the lessons during the training [38]. Additionally, providing follow-up training sessions and/or regular contact with intervention facilitators to provide support and troubleshoot can help ensure intervention fidelity [28-32,45-47,51,65,70]. Training sessions also included emphasis on adapting interventions to the local context and using culturally relevant examples [49,50,52,53,69,71]. The interventions included here underscore the importance of mentors and role-models who go beyond teaching nutrition information to modeling healthy behaviors themselves, which has been identified previously in the literature [74,75]. Additionally, when interventions engage trainers and allow them to connect their interests-whether in sports, gardening, or the arts-to nutrition, the youth receiving the intervention will also be more engaged [48,52,53].

Our second dimension focused on the intervention content. We found fruit and vegetable consumption $[24-26,34,37,48-50,52-54,60,68,69]$, healthy beverages $[23,33,34,39-44,46$, $47,59,61,66]$, and healthy breakfast $[23,33,38,40,45,48-50,52-54,61,68]$ to be common topics. Beyond basic nutrition information, the interventions in this review commonly included goal setting $[38,49-51,60]$, building skills to identify healthy options (including reading food labels) [52-54,59,60], and developing strategies to make healthy choices through an awareness of the food environment context $[40-44,55,58,62,63]$. Interventions included in this review also indicated that youth can be change agents in their communities and advocate for healthier food options in their school and neighborhoods $[55,58,63]$. In Leung et al., the intervention aimed to understand youth perceptions of food justice in their community using photovoice and equip them to promote positive change in their community food environment [55].

The third dimension focused on the format and delivery of the interventions, which as might be expected, varied by setting. Classroom based interventions followed a more structured curriculum, as did some afterschool programs, while other interventions relied on informal conversations among peers to disseminate information. When peers were delivering interventions, less structure sometimes led to less consistency $[40,65]$. One of the key findings within this theme was creating nutrition messages that are positive and simple, especially if the intervention is delivered in a less structured context outside the classroom $[39,41-44,66]$. Smit et al. and Franken et al. demonstrated this with their water promotion intervention implemented in the Netherlands and Aruba, respectively. The main intervention message was framed positively, encouraging water consumption, rather than discouraging sugar-sweetened beverage consumption, yet participants still reported significant decreases in their intake of sugar-sweetened beverages $[39,66]$.

Our fourth and fifth dimensions synthesized outcomes and feedback from the youth participating in the intervention and from those trained to deliver the intervention, when measured. We were particularly interested in youth engagement, receptivity, and feedback provided through surveys and focus groups. Participant engagement and receptivity were measured through a wide range of approaches, when they were actually included as an evaluation metric. Only three interventions explicitly mentioned using 
student satisfaction surveys [28-33,52,53], and all three used different scales. Other interventions obtained feedback from those delivering the intervention or observers about youth engagement [28-32,41-44,64], making it difficult to compare receptivity across interventions. Focus groups were helpful in identifying which nutrition messages were most commonly retained, the components of the interventions that participants most enjoyed, and barriers to making dietary changes. For example, both Luesse et al. and Molaison et al. heard from youth that the lack of availability of healthy foods at home and in their communities made it difficult to make healthy choices [60,62]. Feedback from those delivering the intervention was reported less often, but both Foley et al. and Gittlesohn et al. obtained feedback from the cross-age peers who delivered the intervention and found that the older youth were implementing what they were teaching in their own lives $[38,41-44]$. We extracted data on the types of outcomes that were measured in the interventions, which commonly included anthropometric data, dietary intake, and knowledge, attitudes and behaviors related to healthy eating, but we did not focus on the results of these outcome measures themselves.

While evaluation of intervention efficacy is undeniably essential, improving youth health outcomes is a long-term objective, making it difficult to quantify success in the short-term with anthropometric measurements or behavioral questionnaires. Although BMI is well-correlated with fat mass and percent body fat in youth, it can be difficult to discern whether BMI reductions post-intervention actually indicate a reduction in adiposity, the more important result for improving health outcomes [76,77]. Additionally, changes in BMI may not necessarily reflect dietary shifts, as a number of factors, including physical activity and developmental changes, also have an effect on BMI. Furthermore, dietary assessment methods for youth yield imprecise information, and validity tends to be lower for food frequency questionnaires-the type of evaluation tool favored in the interventions included in this review due to their lower administrative burden [78]. Where resources are not available to measure long-term changes in dietary behaviors and outcomes such as body composition or biochemical markers of chronic disease risk, we posit that information about youth and trainer engagement, such as the content extracted in this review, provides good indication of whether an intervention will influence the habits of youth, leading to improved nutrition outcomes and health over the long term.

\subsection{Limitations}

One of the major limitations of this review was the variability in process and outcome measures used to evaluate the efficacy of the interventions. Such variability, as well as the limitations of outcome evaluation measures described above, make it difficult to determine which methodologies or designs would be most efficacious for training those delivering the intervention and for improving youth nutrition outcomes. The variability in process measures also limited our ability to assess youth acceptability of the interventions in a systematic way, though we were still able to identify components that were particularly engaging for youth across multiple interventions. The review was also limited in that few of the studies examined the effect of the intervention on the "trainers," which could serve as another important marker of long-term impact in creating a culture of health for youth. Finally, while including a wide range of study types was beneficial in the additional insight provided through qualitative methods and study protocols, it did limit the depth of our quality assessment

\subsection{Application of Findings}

We incorporated the major themes identified through this review into a nutrition training for the COACHES project, a sports-based youth development intervention targeting middle school students in New Orleans, Louisiana. In the initial training for the near-peer coaches working with the youth, we emphasized three key messages that were simple, positive, and focused: fruit and vegetable consumption, maintaining hydration-primarily through water intake, and eating breakfast regularly. These three messages were included 
in nearly every intervention in this study and are highly relevant for our target population, particularly due to their participation in sports $[79,80]$. In the initial training, we covered goal setting, as well as skills and strategies for making healthy choices, in the context of the three key messages. We communicated this content to the coaches through interactive games and activities that they could then use with their youth. We conducted a follow-up training four months after the initial training to address strategies for overcoming both internal (e.g., reluctance to share about food choices due to self-consciousness) and external (e.g., lack of affordable, healthy options in the food environment) barriers youth face when seeking to make healthful dietary choices, and we used role-playing activities to address scenarios that coaches encounter in their work.

\section{Conclusions}

This review provides important insights and enhances understanding of the design, methodology, and structure of train-the-trainer nutrition education interventions for middle school youth in U.S. and U.S.-comparable urban settings. Several of the studies included here also illuminate barriers that youth face to healthy eating, especially in urban environments with limited affordable, fresh food options and an abundance of inexpensive, high-calorie processed foods. In middle school, youth have increasing, though not complete, agency over their food choices, and conversation about the food environment at home, at school, and in the broader community should be included in nutrition education interventions, as should devising strategies to navigate those food environments in healthy ways. One of the limitations of this review was the lack of consistent methods for evaluating youth receptivity of the intervention. Further research should include more measures of engagement and youth feedback, not only immediately post-intervention, but also after several months post intervention to determine whether messages have stayed with the youth and continue to motivate healthy behavior change.

Supplementary Materials: The following are available online at https:/ /www.mdpi.com/article/10 $.3390 /$ nu13082749/s1. Figure S1: Electronic search strategy for PubMed/Medline Database.

Author Contributions: Conceptualization, C.S.P., W.G., J.M. and J.M.S.; methodology, C.S.P.; article review and data extraction, L.B., G.D., A.M. and S.G.; writing-original draft preparation, C.S.P.; writing-review and editing, W.G., J.M., J.M.S.; All authors have read and agreed to the published version of the manuscript.

Funding: This research was funded by the U.S. Department of Health and Human Services Office of Minority Health, grant number CPIMP191186.

Acknowledgments: The 2020-2021 New Orleans-based Up2 Us Coaches; Up2Us staff-including Jerita Mitchell, Katie Rawlings, and the entire training team; and physical activity training partner Natasha Cruz were all instrumental in developing and delivering the trainings that came from the application of these review findings.

Conflicts of Interest: The authors declare no conflict of interest. The funders had no role in the design of the study; in the collection, analyses, or interpretation of data; in the writing of the manuscript, or in the decision to publish the results.

\section{References}

1. Herman, K.M.; Craig, C.L.; Gauvin, L.; Katzmarzyk, P.T. Tracking of obesity and physical activity from childhood to adulthood: The Physical Activity Longitudinal Study. Int. J. Pediatr. Obes. 2009, 4, 281-288. [CrossRef]

2. Megari, K. Quality of life in chronic disease patients. Health Psychol. Res. 2013, 1, e27. [CrossRef]

3. Hales, C.M.; Carroll, M.D.; Fryar, C.D.; Ogden, C.L. Prevalence of Obesity Among Adults and Youth: United States, 2015-2016. NCHS Data Brief, No. 288; National Center for Health Statistics: Hyattsville, MD, USA, 2017.

4. Ogden, C.L.; Carroll, M.D.; Fakhouri, T.H.; Hales, C.; Fryar, C.D.; Li, X.; Freedman, D.S. Prevalence of Obesity among Youths by Household Income and Education Level of Head of Household-United States 2011-2014. MMWR Morb. Mortal Wkly. Rep. 2018, 67, 186-189. [CrossRef] 
5. National Survey of Children's Health Interactive Data Query: 2018-2019 National Survey of Children's Health. Baltimore, MD: Data Resource Center for Child and Adolescent Health. Available online: https:/ / www.childhealthdata.org/browse/survey / results? $\mathrm{q}=7620 \& \mathrm{r}=1$ (accessed on 10 March 2021).

6. Kim, S.A.; Moore, L.V.; Galuska, D. Vital Signs: Fruit and vegetable intake among children-United States, 2003-2010. MMWR 2014, 63, 671-676. [PubMed]

7. Drewnowski, A.; Rehm, C.D.; Constant, F. Water and beverage consumption among children age 4-13 years in the United States: Analyses of 2005-2010 NHANES data. Nutr. J. 2013, 12, 85. [CrossRef] [PubMed]

8. Pérez-Rodrigo, C.; Wind, M.; Hildonen, C.; Bjelland, M.; Aranceta, J.; Klepp, K.-I.; Brug, J. The Pro Children Intervention: Applying the Intervention Mapping Protocol to Develop a School-Based Fruit and Vegetable Promotion Programme. Ann. Nutr. Metab. 2005, 49, 267-277. [CrossRef] [PubMed]

9. Langford, R.; Bonell, C.; Jones, H.; Campbell, R. Obesity prevention and the Health promoting Schools framework: Essential components and barriers to success. Int. J. Behav. Nutr. Phys. Act. 2015, 12, 1-17. [CrossRef]

10. Kamath, C.C.; Vickers, K.S.; Ehrlich, A.; McGovern, L.; Johnson, J.; Singhal, V.; Paulo, R.; Hettinger, A.; Erwin, P.J.; Montori, V.M. Behavioral Interventions to Prevent Childhood Obesity: A Systematic Review and Metaanalyses of Randomized Trials. J. Clin. Endocrinol. Metab. 2008, 93, 4606-4615. [CrossRef] [PubMed]

11. Meiklejohn, S.; Ryan, L.; Palermo, C. A Systematic Review of the Impact of Multi-Strategy Nutrition Education Programs on Health and Nutrition of Adolescents. J. Nutr. Educ. Behav. 2016, 48, 631-646.e1. [CrossRef]

12. Murimi, M.W.; Moyeda-Carabaza, A.F.; Nguyen, B.; Saha, S.; Amin, R.; Njike, V. Factors that contribute to effective nutrition education interventions in children: A systematic review. Nutr. Rev. 2018, 76, 553-580. [CrossRef]

13. Moher, D.; Liberati, A.; Tetzlaff, J.; Altman, D.G.; The PRISMA Group. Preferred Reporting Items for Systematic Reviews and Meta-Analyses: The PRISMA Statement. PLoS Med. 2009, 6, e1000097. [CrossRef]

14. Cherry, M.G.; Smith, H.; Perkins, E.; Boland, A. Reviewing Qualitative Evidence. In Doing a Systematic Review: A Student's Guide, 2nd ed.; Boland, A., Cherry, M.G., Dicksson, R., Eds.; Sage Publications: London, UK, 2017; Chapter 11; pp. $193-222$.

15. Oliver, S.R.; Rees, R.; Clarke-Jones, L.; Milne, R.; Oakley, A.R.; Gabbay, J.; Stein, K.; Buchanan, P.; Gyte, G. A multidimensional conceptual framework for analysing public involvement in health services research. Health Expect. 2008, 11, 72-84. [CrossRef]

16. Oliver, S.; Clarke-Jones, L.; Rees, R.; Milne, R.; Buchanan, P.; Gabbay, J.; Gyte, G.; Oakley, A.; Stein, K. Involving consumers in research and development agenda setting for the NHS: Developing an evidence-based approach. Health Technol. Assess. 2004, 8, 1-148. [CrossRef]

17. Brunton, G.; Oliver, S.; Thomas, J. Innovations in framework synthesis as a systematic review method. Res. Synth. Methods 2020, 11,316-330. [CrossRef] [PubMed]

18. Noyes, J.; Booth, A.; Cargo, M. Qualitative evidence. In Cochrane Handbook for Systematic Reviews of Interventions, Version 6.2; Higgins, J.P.T., Thomas, J., Chandler, J., Cumpston, M., Li, T., Page, M.J., Welch, V.A., Eds.; Cochrane: London, UK, 2021; Chapter 21; updated on February 2021; Available online: www.training.cochrane.org/handbook (accessed on 23 July 2021).

19. Critical Appraisal Skills Programme. CASP Qualitative Checklist. Available online: https://casp-uk.net/wp-content/uploads/ 2018/01/CASP-Qualitative-Checklist-2018.pdf (accessed on 23 July 2021).

20. Carroll, C.; Booth, A.; Lloyd-Jones, M. Should We Exclude Inadequately Reported Studies from Qualitative Systematic Reviews? An Evaluation of Sensitivity Analyses in Two Case Study Reviews. Qual. Health Res. 2012, 22, 1425-1434. [CrossRef] [PubMed]

21. Arlinghaus, K.R.; Moreno, J.; Reesor, L.; Hernandez, D.C.; Johnston, C.A. Compañeros: High School Students Mentor Middle School Students to Address Obesity Among Hispanic Adolescents. Prev. Chronic Dis. 2017, 14, E92. [CrossRef]

22. Baskin, M.L.; Zunker, C.; Worley, C.B.; Dial, B.; Kimbrough, L. Design and implementation of a pilot obesity prevention program in a low-resource school. Health Educ. 2008, 109, 66-85. [CrossRef]

23. Bell, S.L.; Audrey, S.; Cooper, A.; Noble, S.; Campbell, R. Lessons from a peer-led obesity prevention programme in English schools. Health Promot. Int. 2017, 32, 250-259. [CrossRef]

24. Bogart, L.M.; Elliott, M.N.; Cowgill, B.O.; Klein, D.J.; Hawes-Dawson, J.; Uyeda, K.; Schuster, M.A. Two-Year BMI Outcomes From a School-Based Intervention for Nutrition and Exercise: A Randomized Trial. Pediatrics 2016, 137, e20152493. [CrossRef]

25. Bogart, L.M.; Cowgill, B.O.; Elliott, M.N.; Klein, D.J.; Hawes-Dawson, J.; Uyeda, K.; Elijah, J.; Binkle, D.G.; Schuster, M.A. A Randomized Controlled Trial of Students for Nutrition and eXercise: A Community-Based Participatory Research Study. J. Adolesc. Health 2014, 55, 415-422. [CrossRef]

26. Bogart, L.M.; Elliott, M.N.; Uyeda, K.; Hawes-Dawson, J.; Klein, D.J.; Schuster, M.A. Preliminary Healthy Eating Outcomes of SNaX, a Pilot Community-Based Intervention for Adolescents. J. Adolesc. Health 2011, 48, 196-202. [CrossRef] [PubMed]

27. Bukhari, A.; Fredericks, L.; Wylie-Rosett, J. Strategies to Promote High School Students' Healthful Food Choices. J. Nutr. Educ. Behav. 2011, 43, 414-418. [CrossRef]

28. Contento, I.R.; Koch, P.A.; Lee, H.; Calabrese-Barton, A. Adolescents Demonstrate Improvement in Obesity Risk Behaviors after Completion of Choice, Control \& Change, a Curriculum Addressing Personal Agency and Autonomous Motivation. J. Am. Diet. Assoc. 2010, 110, 1830-1839. [CrossRef] [PubMed]

29. Contento, I.R.; Koch, P.A.; Lee, H.; Sauberli, W.; Calabrese-Barton, A. Enhancing Personal Agency and Competence in Eating and Moving: Formative Evaluation of a Middle School Curriculum-Choice, Control, and Change. J. Nutr. Educ. Behav. 2007, 39, S179-S186. [CrossRef] 
30. Gray, H.L.; Contento, I.R.; Koch, P.A.; Di Noia, J. Mediating Mechanisms of Theory-Based Psychosocial Determinants on Behavioral Changes in a Middle School Obesity Risk Reduction Curriculum Intervention, Choice, Control, and Change. Child Obes. 2016, 12, 348-359. [CrossRef]

31. Gray, H.L.; Contento, I.R.; Koch, P.A. Linking implementation process to intervention outcomes in a middle school obesity prevention curriculum, 'Choice, Control and Change'. Health Educ. Res. 2015, 30, 248-261. [CrossRef]

32. Lee, H.; Contento, I.R.; Koch, P. Using a Systematic Conceptual Model for a Process Evaluation of a Middle School Obesity Risk-Reduction Nutrition Curriculum Intervention: Choice, Control \& Change. J. Nutr. Educ. Behav. 2013, 45, 126-136. [CrossRef]

33. Dubuy, V.; De Cocker, K.; De Bourdeaudhuij, I.; Maes, L.; Seghers, J.; Lefevre, J.; De Martelaer, K.; Brooke, H.; Cardon, G. Evaluation of a real world intervention using professional football players to promote a healthy diet and physical activity in children and adolescents from a lower socio-economic background: A controlled pretest-posttest design. BMC Public Health 2014, 14, 457. [CrossRef]

34. Duncan, S.; Stewart, T.; McPhee, J.; Borotkanics, R.; Prendergast, K.; Zinn, C.; Meredith-Jones, K.; Taylor, R.; McLachlan, C.; Schofield, G. Efficacy of a compulsory homework programme for increasing physical activity and improving nutrition in children: A cluster randomised controlled trial. Int. J. Behav. Nutr. Phys. Act. 2019, 16, 1-12. [CrossRef]

35. El Rayess, F.; Gandhi, M.; Mennillo, H. Mark, Set, Go! School-Based Nutrition and Physical Activity Program: A Five-Year Evaluation. Rhode Isl. Med. J. 2017, 100, 39-44.

36. Fahlman, M.M.; Dake, J.A.; McCaughtry, N.; Martin, J. A Pilot Study to Examine the Effects of a Nutrition Intervention on Nutrition Knowledge, Behaviors, and Efficacy Expectations in Middle School Children. J. Sch. Health 2008, 78, 216-222. [CrossRef] [PubMed]

37. Fairclough, S.J.; Hackett, A.F.; Davies, I.G.; Gobbi, R.; Mackintosh, K.A.; Warburton, G.L.; Stratton, G.; Van Sluijs, E.M.; Boddy, L.M. Promoting healthy weight in primary school children through physical activity and nutrition education: A pragmatic evaluation of the CHANGE! Randomised intervention study. BMC Public Health 2013, 13, 626. [CrossRef]

38. Foley, B.C.; Shrewsbury, V.A.; Hardy, L.L.; Flood, V.M.; Byth, K.; Shah, S. Evaluation of a peer education program on student leaders' energy balance-related behaviors. BMC Public Health 2017, 17, 8. [CrossRef] [PubMed]

39. Franken, S.C.M.; Smit, C.R.; Buijzen, M. Promoting Water Consumption on a Caribbean Island: An Intervention Using Children's Social Networks at Schools. Int. J. Environ. Res. Public Health 2018, 15, 713. [CrossRef] [PubMed]

40. Gittelsohn, J.; Dennisuk, L.A.; Christiansen, K.; Bhimani, R.; Johnson, A.; Alexander, E.; Lee, M.; Lee, S.H.; Rowan, M.; Coutinho, A.J. Development and implementation of Baltimore Healthy Eating Zones: A youth-targeted intervention to improve the urban food environment. Health Educ. Res. 2013, 28, 732-744. [CrossRef]

41. Gittelsohn, J.; Steeves, E.A.; Mui, Y.; Kharmats, A.Y.; Hopkins, L.C.; Dennis, D. B'More Healthy Communities for Kids: Design of a multi-level intervention for obesity prevention for low-income African American children. BMC Public Health 2014, 14, 942. [CrossRef] [PubMed]

42. Sato, P.M.; Steeves, E.A.; Carnell, S.; Cheskin, L.J.; Trude, A.C.; Shipley, C.; Ruiz, M.J.M.; Gittelsohn, J. A youth mentor-led nutritional intervention in urban recreation centers: A promising strategy for childhood obesity prevention in low-income neighborhoods. Health Educ. Res. 2016, 31, 195-206. [CrossRef]

43. Trude, A.C.B.; Steeves, E.A.; Shipley, C.; Surkan, P.J.; Sato, P.D.M.; Estep, T.; Clanton, S.; Lachenmayr, L.; Gittelsohn, J. A Youth-Leader Program in Baltimore City Recreation Centers: Lessons Learned and Applications. Health Promot. Pract. 2018, 19, 75-85. [CrossRef]

44. Steeves, E.A.; Trude, A.C.B.; Ruggiero, C.F.; Ruiz, M.J.M.; Jones-Smith, J.; Porter, K.P.; Cheskin, L.; Hurley, K.; Hopkins, L.; Gittelsohn, J. Perceptions and Impact of a Youth-led Childhood Obesity Prevention Intervention among Youth-leaders. J. Hunger. Environ. Nutr. 2019, 16, 213-234. [CrossRef]

45. Heo, M.; Jimenez, C.C.; Lim, J.; Isasi, C.R.; Blank, A.E.; Lounsbury, D.W.; Fredericks, L.; Bouchard, M.; Faith, M.S.; Wylie-Rosett, J.; et al. Effective nationwide school-based participatory extramural program on adolescent body mass index, health knowledge and behaviors. BMC Pediatr. 2018, 18, 7. [CrossRef]

46. Irwin, C.; Irwin, R.; Richey, P.; Miller, M.; Boddie, J.; Dickerson, T. Get fit with the Grizzlies: A community-school-home initiative to fight childhood obesity led by a professional sports organization. Stud. Health Technol. Inform. 2012, 172, $163-167$.

47. Irwin, C.C.; Miller, M.E.; Somes, G.W.; Richey, P.A.; Irwin, R.L. Get Fit with the Grizzlies: A Community-School-Home Initiative to Fight Childhood Obesity. J. Sch. Health 2010, 80, 333-339. [CrossRef]

48. Jackson, C.J.; Mullis, R.M.; Hughes, M. Development of a theater-based nutrition and physical activity intervention for lowincome, urban, African American adolescents. Prog. Community Health Partnersh. Res. Educ. Action 2010, 4, 89-98. [CrossRef] [PubMed]

49. Kipping, R.R.; Howe, L.; Jago, R.; Campbell, R.; Wells, S.; Chittleborough, C.; Mytton, J.; Noble, S.M.; Peters, T.; Lawlor, D.A. Effect of intervention aimed at increasing physical activity, reducing sedentary behaviour, and increasing fruit and vegetable consumption in children: Active for Life Year 5 (AFLY5) school based cluster randomised controlled trial. BMJ 2014, 348 , g3256. [CrossRef]

50. Lawlor, D.A.; Jago, R.; Noble, S.M.; Chittleborough, C.R.; Campbell, R.; Mytton, J.; Howe, L.D.; Peters, T.J.; Kipping, R.R. The Active for Life Year 5 (AFLY5) school based cluster randomised controlled trial: Study protocol for a randomized controlled trial. Trials 2011, 12, 181. [CrossRef] 
51. Koch, P.A.; Contento, I.R.; Gray, H.L.; Burgermaster, M.; Bandelli, L.; Abrams, E.; Di Noia, J. Food, Health, \& Choices: Curriculum and Wellness Interventions to Decrease Childhood Obesity in Fifth-Graders. J. Nutr. Educ. Behav. 2019, 51, 440-455. [CrossRef]

52. Kohlstadt, I.; Gittelsohn, J.; Fang, Y. NutriBee Intervention Improves Diet and Psychosocial Outcomes by Engaging Early Adolescents from Diverse and Disadvantaged Communities. J. Am. Coll. Nutr. 2016, 35, 1-9. [CrossRef]

53. Kohlstadt, I.C.; Steeves, E.T.A.; Rice, K.; Gittelsohn, J.; Summerfield, L.M.; Gadhoke, P. Youth peers put the "invent" into NutriBee's online intervention. Nutr. J. 2015, 14, 1-8. [CrossRef]

54. Lepe, S.; Goodwin, J.; Mulligan, K.T.; Balestracci, K.; Sebelia, L.; Greene, G. Process Evaluation of a Policy, Systems, and Environmental Change Intervention in an Urban School District. J. Nutr. Educ. Behav. 2019, 51, 307-317. [CrossRef] [PubMed]

55. Leung, M.M.; Agaronov, A.; Entwistle, T.; Harry, L.; Sharkey-Buckley, J.; Freudenberg, N. Voices through Cameras. Health Promot. Pract. 2016, 18, 211-220. [CrossRef] [PubMed]

56. Li, Y.; Hu, X.; Zhang, Q.; Liu, A.; Fang, H.; Hao, L.; Duan, Y.; Xu, H.; Shang, X.; Ma, J.; et al. The nutrition-based comprehensive intervention study on childhood obesity in China (NISCOC): A randomised cluster controlled trial. BMC Public Health 2010, 10, 229. [CrossRef] [PubMed]

57. Xu, H.; Li, Y.; Zhang, Q.; Hu, X.L.; Liu, A.; Du, S.; Li, T.; Guo, H.; Li, Y.; Xu, G.; et al. Comprehensive school-based intervention to control overweight and obesity in China: A cluster randomized controlled trial. Asia Pac. J. Clin. Nutr. 2017, 26, 1139-1151.

58. Linton, L.S.; Edwards, C.C.; Woodruff, S.I.; Millstein, R.A.; Moder, C. Youth Advocacy as a Tool for Environmental and Policy Changes That Support Physical Activity and Nutrition: An Evaluation Study in San Diego County. Prev. Chronic Dis. 2014, 11, E46. [CrossRef]

59. Lo, E.; Coles, R.; Humbert, M.L.; Polowski, J.; Henry, C.J.; Whiting, S.J. Beverage intake improvement by high school students in Saskatchewan, Canada. Nutr. Res. 2008, 28, 144-150. [CrossRef]

60. Luesse, H.B.; Luesse, J.E.; Lawson, J.; Koch, P.A.; Contento, I.R. In Defense of Food Curriculum: A Mixed Methods Outcome Evaluation in Afterschool. Health Educ. Behav. 2019, 46, 612-625. [CrossRef] [PubMed]

61. Mihas, C.; Mariolis, A.; Manios, Y.; Naska, A.; Arapaki, A.; Mariolis-Sapsakos, T.; Tountas, Y. Evaluation of a nutrition intervention in adolescents of an urban area in Greece: Short- and long-term effects of the VYRONAS study. Public Health Nutr. 2009, 13, 712-719. [CrossRef]

62. Molaison, E.F.; Connell, C.L.; Stuff, J.E.; Yadrick, M.K.; Bogle, M. Influences on Fruit and Vegetable Consumption by Low-Income Black American Adolescents. J. Nutr. Educ. Behav. 2005, 37, 246-251. [CrossRef]

63. Necheles, J.W.; Chung, E.Q.; Hawes-Dawson, J.; Ryan, G.W.; Williams, S.B.; Holmes, H.N.; Wells, K.B.; Vaiana, M.E.; Schuster, M.A.; Williams, L.B. The Teen Photovoice Project: A Pilot Study to Promote Health Through Advocacy. Prog. Community Health Partnersh. Res. Educ. Action 2007, 1, 221-229. [CrossRef] [PubMed]

64. Olivares, S.; Zacarías, I.; Andrade, M.; Kain, J.; Lera, L.; Vio, F.; Morón, C. Nutrition Education in Chilean Primary Schools. Food Nutr. Bull. 2005, 26, S179-S185. [CrossRef]

65. Saez, L.; Legrand, K.; Alleyrat, C.; Ramisasoa, S.; Langlois, J.; Muller, L.; Omorou, A.Y.; De Lavenne, R.; Kivits, J.; LeComte, E.; et al. Using facilitator-Receiver peer dyads matched according to socioeconomic status to promote behaviour change in overweight adolescents: A feasibility study. BMJ Open 2018, 8, e019731. [CrossRef] [PubMed]

66. Smit, C.R.; de Leeuw, R.N.; Bevelander, K.E.; Burk, W.J.; Buijzen, M. A social network-based intervention stimulating peer influence on children's self-reported water consumption: A randomized control trial. Appetite 2016, 103, 294-301. [CrossRef]

67. Stock, S.; Miranda, C.; Evans, S.; Plessis, S.; Ridley, J.; Yeh, S.; Chanoine, J.-P. Healthy Buddies: A Novel, Peer-Led Health Promotion Program for the Prevention of Obesity and Eating Disorders in Children in Elementary School. Pediatrics 2007, 120, e1059-e1068. [CrossRef]

68. Tamiru, D.; Argaw, A.; Gerbaba, M.; Ayana, G.; Nigussie, A.; Belachew, T. Effect of integrated school-based nutrition education on optimal dietary practices and nutritional status of school adolescents in Southwest of Ethiopia: A quasi-experimental study. Int. J. Adolesc. Med. Health 2016, 29, 20160015. [CrossRef] [PubMed]

69. Tsai, P.-Y.; Boonpleng, W.; McElmurry, B.J.; Park, C.G.; McCreary, L. Lessons Learned in Using TAKE 10! With Hispanic Children. J. Sch. Nurs. 2009, 25, 163-172. [CrossRef]

70. Tucker, S.; Lanningham-Foster, L.M. Nurse-Led School-Based Child Obesity Prevention. J. Sch. Nurs. 2015, 31, 450-466. [CrossRef]

71. Wright, K.; Norris, K.; Giger, J.N.; Suro, Z. Improving Healthy Dietary Behaviors, Nutrition Knowledge, and Self-Efficacy among Underserved School Children with Parent and Community Involvement. Child. Obes. 2012, 8, 347-356. [CrossRef]

72. Zhou, Z.; Li, S.; Yin, J.; Fu, Q.; Ren, H.; Jin, T.; Zhu, J.; Howard, J.; Lan, T.; Yin, Z.; et al. Impact on Physical Fitness of the Chinese CHAMPS: A Clustered Randomized Controlled Trial. Int. J. Environ. Res. Public Health 2019, 16, 4412. [CrossRef]

73. Zhou, Z.; Dong, S.; Yin, J.; Fu, Q.; Ren, H.; Yin, Z. Improving Physical Fitness and Cognitive Functions in Middle School Students: Study Protocol for the Chinese Childhood Health, Activity and Motor Performance Study (Chinese CHAMPS). Int. J. Environ. Res. Public Health 2018, 15, 976. [CrossRef]

74. Black, M.M.; Hager, E.R.; Le, K.; Anliker, J.; Arteaga, S.S.; DiClemente, C.; Gittelsohn, J.; Magder, L.; Papas, M.; Snitker, S.; et al. Challenge! Health Promotion/Obesity Prevention Mentorship Model Among Urban, Black Adolescents. Pediatrics 2010, 126, 280-288. [CrossRef] [PubMed]

75. Dzewaltowski, D.A.; Estabrooks, P.A.; Welk, G.; Hill, J.; Milliken, G.; Karteroliotis, K.; Johnston, J.A. Healthy Youth Places: A Randomized Controlled Trial to Determine the Effectiveness of Facilitating Adult and Youth Leaders to Promote Physical Activity and Fruit and Vegetable Consumption in Middle Schools. Health Educ. Behav. 2008, 36, 583-600. [CrossRef] 
76. Institute of Medicine. Fitness Measures and Health Outcomes in Youth; National Academies Press: Washington, DC, USA, 2012.

77. Birch, L.; Perry, R.; Hunt, L.P.; Matson, R.; Chong, A.; Beynon, R.; Hamilton-Shield, J. What change in body mass index is associated with improvement in percentage body fat in childhood obesity? A meta-regression. BMJ Open 2019,9 , e028231. [CrossRef] [PubMed]

78. Tugault-Lafleur, C.N.; Black, J.L.; IBarr, S. A Systematic Review of Methods to Assess Children's Diets in the School Context. Adv. Nutr. 2017, 8, 63-79. [CrossRef] [PubMed]

79. Mangieri, H. Fueling Young Athletes; Human Kinetics: Champaign, IL, USA, 2016.

80. Seebohar, B. Sports Nutrition for Youth Athletes. USA Triathlon. 25 July 2019. Available online: https:/ / www.teamusa.org/USATriathlon/News/Blogs/Multisport-Lab/2019/July/25/Sports-Nutrition-for-Youth-Athletes (accessed on 22 September 2020). 